\title{
Physicochemical properties of $\mathrm{Mn}_{1.45} \mathrm{Co}_{1.45} \mathrm{Cu}_{0.1} \mathrm{O}_{4}$ spinel coating deposited on the Crofer $22 \mathrm{H}$ ferritic steel and exposed to high-temperature oxidation under thermal cycling conditions
}

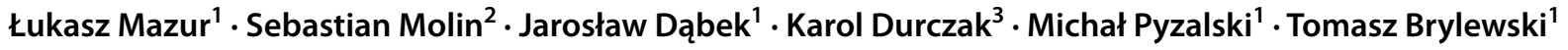

Received: 20 June 2020 / Accepted: 2 May 2021 / Published online: 23 June 2021

(c) The Author(s) 2021

\begin{abstract}
The Crofer $22 \mathrm{H}$ ferritic steel substrate was coated with an $\mathrm{Mn}_{1.45} \mathrm{Co}_{1.45} \mathrm{Cu}_{0.1} \mathrm{O}_{4}$ spinel by means of electrophoresis. After high-temperature oxidation under thermal cycling conditions, the physicochemical properties of the obtained system were evaluated. During 48-h cycles that involved heating the samples up to temperatures of either 750 or $800{ }^{\circ} \mathrm{C}$, the oxidation kinetics of both coated and unmodified steel approximately obeyed the parabolic rate law. The unmodified steel was oxidized at a higher rate than the system consisting of the substrate and the coating. In its bulk form, the spinel consisted entirely of the cubic phase and it exhibited high electrical conductivity. The $\mathrm{Mn}_{1.45} \mathrm{Co}_{1.45} \mathrm{Cu}_{0.1} \mathrm{O}_{4}$ coating, on the other hand, was compact and consisted of two phases - the cubic and the tetragonal one — and it was characterized by good adhesion to the metallic substrate. After cyclic oxidation studies conducted for the two investigated temperatures $\left(750\right.$ or $\left.800{ }^{\circ} \mathrm{C}\right)$, the coating was determined to provide a considerable improvement in the electrical properties of the Crofer $22 \mathrm{H}$ ferritic steel, as demonstrated by the area-specific resistance values measured for the steel/coating system. The evaporation rate of chromium measured for these samples likewise indicates that the coating is capable of acting as an effective barrier against the formation of volatile compounds of chromium. The $\mathrm{Mn}_{1.45} \mathrm{Co}_{1.45} \mathrm{Cu}_{0.1} \mathrm{O}_{4}$ spinel can therefore be considered a suitable material for a coating on the Crofer $22 \mathrm{H}$ ferritic steel, with intermediate-temperature solid oxide electrolyzer cells as the target application.
\end{abstract}

Keywords Solid oxide electrolyzer cells (SOEC) · Metallic interconnects · Cobalt manganese spinels · Oxidation kinetics · Electrical conductivity

\section{Introduction}

Energy storage has become as important to the development of human civilization as energy generation. Energy storage technologies allow surplus electrical energy to be converted into the chemical energy of fuel, which can be utilized whenever required. One of the technologies with the

Tomasz Brylewski

brylew@agh.edu.pl

1 Faculty of Materials Science and Ceramics, AGH University of Science and Technology, Al. Mickiewicza 30, 30-059 Krakow, Poland

2 Faculty of Electronics, Telecommunications and Informatics, Gdansk University of Technology, Ul. Narutowicza 11/12, 80-233 Gdansk, Poland

3 Institute of Biosystems Engineering, Faculty of Agronomy and Bioengineering, Poznan University of Life Sciences, Ul. Wojska Polskiego 50, 60-627 Poznan, Poland most potential in this regard is the solid oxide electrolyzer cell (SOEC) [1-4]. It is worth noting that the production of hydrogen via the electrolysis of water is more efficient in terms of conversion than the thermochemical and photocatalytic methods [5]. Since they operate at high temperatures, SOECs are capable of converting electrical energy not only into hydrogen, but also more complex gas fuels, such as syngas. This gas is a mixture of hydrogen and carbon monoxide, and it can be used to synthesize numerous liquid fuels, including ethanol, methanol, and synthetic gasoline [6, 7]. Last but not least, the production of syngas in SOECs with the use of co-electrolysis of water vapour and carbon dioxide might be considered one of the ways in which the climate changes taking place on Earth can be somewhat mitigated.

The principle of operation of a SOEC is the reversal of the reactions that occur in a solid oxide fuel cell (SOFC). SOECs are constructed using the same materials and engineering solutions as SOFCs [1, 3, 4, 8]. However, the reversal of the direction in which the electrochemical reaction 
proceeds and a different composition of gas mixtures that fuel the system causes an accelerated degradation of SOEC components. The interconnect, which is also known as a bipolar plate, is the basic structural component in both types of devices. It has a number of functions: it connects individual fuel or electrolyzer cells in series, gives the entire construction rigidity, and it supplies the gas reagents to the anode and cathode spaces via the channels located on both of its sides [9-13].

Interconnects applied in SOECs that operate at temperatures of up to $800^{\circ} \mathrm{C}$ are generally manufactured from highchromium ferritic stainless steels (FSS), which contain at least 22 mass\% of chromium [9-16]. The thermal expansion coefficient of such steels $\left(11.5-14.0 \times 10^{-6} \mathrm{~K}^{-1}\right.$ [11]) is similar to the corresponding coefficients of the ceramic components of the electrolyzer, namely the anode $\left(12.8 \times 10^{-6} \mathrm{~K}^{-1}\right.$ for $\mathrm{La}_{0.69} \mathrm{Sr}_{0.30} \mathrm{MnO}_{3}$ [17]), cathode $\left(11.9 \times 10^{-6} \mathrm{~K}^{-1}\right.$ for NiO-YSZ [17]), and the electrolyte $\left(10.5 \times 10^{-6} \mathrm{~K}^{-1}\right.$ for YSZ [17]). Compared to ceramic interconnects, metallic ones have a number of advantages, including high mechanical strength, gas-tightness, and low cost of fabrication. Their main weakness is their low resistance to oxidation in reaction gas media. A chromia $\left(\mathrm{Cr}_{2} \mathrm{O}_{3}\right)$ scale gradually grows on their surface during the operation of the SOEC [9-20]. This in turn causes a continuous increase in the area-specific resistance (ASR) of the interconnect. After prolonged use of the electrolyzer, this increase may significantly affect the power efficiency of the entire unit. There is also another adverse phenomenon that occurs as a result of a reaction between the chromia scale and some of the gas oxidants (e.g. oxygen, water vapour, carbon dioxide), namely the formation of volatile chromium compounds. Such compounds tend to react with the material of the anode and cathode, causing their catalytic properties to diminish [21-23].

A number of ways to reduce the impact of the aforementioned phenomena have been proposed. One of them is the surface modification of metallic interconnects, which involves the deposition of a protective-conducting layer by means of various methods, including screen-printing [24-28], dip-coating [29], electroplating [30-34], RF-sputtering [35], cost-effective atmospheric plasma spray (APS) $[36,37]$ and large area filtered arc deposition (LAFAD) [38]. The materials that seem most suitable for such modifications based on current research are spinels with the following compositions: (Mn, Co) $)_{2} \mathrm{O}_{3}$ [39-46], $(\mathrm{Cu}, \mathrm{Mn})_{2} \mathrm{O}_{4}$ [47-49], (Co, Mn, Me) ${ }_{2} \mathrm{O}_{3}$ (where $\mathrm{Me}: \mathrm{Cu}, \mathrm{Ni}, \mathrm{Fe}, \mathrm{Ag}, \mathrm{Ce}, \mathrm{Y}$ ) [50-57]. The prerequisites met by these materials meet are high electronic conductivity, a very low coefficient of oxygen diffusion in the oxygen sublattice, and low $\mathrm{O}^{2-}$ anion and $\mathrm{Cr}^{3+}$ cation components of electrical conductivity [58-60]. Last but not least, these spinels are effective at blocking the outward diffusion of chromium and its evaporation $[61,62]$.
Since a bipolar interconnect has a relatively complex shape, with a system of channels that supply fuel and the oxidant in the interior of a fuel cell stack, it appears that the most efficient method which can be used to deposit homogeneous spinel layers is electrophoretic deposition (EPD) [63-68].

Of the many spinel compounds that had thus far been investigated as materials for protective-conducting coatings used to modify the surface of metallic interconnects applied in intermediate-temperature solid oxide electrolyzer cells, cobalt-manganese spinels with an addition of copper are particularly worth noting $[28,50,52,54,58,59]$.

The results of research on the physicochemical properties of $\mathrm{Cu}-\mathrm{Mn}-\mathrm{Co}-\mathrm{O}$ spinels which had a copper admixture introduced into the crystal lattice of cobalt-manganese spinel indicate that it is possible to simultaneously increase their electrical conductivity and reduce their sintering temperature $[50,69]$. The X-ray diffraction studies conducted for $\mathrm{Cu}_{y} \mathrm{Mn}_{1.5-0.5 y} \mathrm{Co}_{1.5-0.5 y} \mathrm{O}_{4}$ powders (where $y=0.1,0.3$ or 0.5 ) obtained using the citrate-gel method have shown the sole presence of the cubic phase $\left(\mathrm{MnCo}_{2} \mathrm{O}_{4}\right)$, whereas the samples which had no copper addition contained both the cubic and the tetragonal phase $\left(\mathrm{Mn}_{2} \mathrm{CoO}_{4}\right)$ [50]. The introduction of copper into the crystal lattice of the $\mathrm{Mn}_{1.5} \mathrm{Co}_{1.5} \mathrm{O}_{4}$ oxide clearly causes the cubic phase to stabilize. This phase is characterized by higher electrical conductivity than the tetragonal one [28, 50,69]. Moreover, if transition metal cations such as $\mathrm{Cu}, \mathrm{Ni}$, and $\mathrm{Fe}[51,69-72]$ are considered, $\mathrm{Cu}$ is the only element that - when added to the $(\mathrm{Mn}, \mathrm{Co})_{3} \mathrm{O}_{4}$ spinel-significantly improves its thermal expansion coefficient (TEC) and allows it to match the coefficient of ferritic stainless steel $[28,69]$; this improves the adhesion of the coating to the metal substrate. As shown by the data reported in [52], the deposition of a dense coating consisting of $\mathrm{Cu}_{0.2} \mathrm{Mn}_{1.4} \mathrm{Co}_{1.4} \mathrm{O}_{4}$ with a cubic structure on the Crofer 22 APU ferritic steel by means of the powder reduction technique ensures high electrical conductivity and a good match between the thermal expansion coefficients of the coating and the metallic interconnect. In this case, the reported ASR values were below $4 \mathrm{~m} \Omega \mathrm{cm}^{2}$, even after the coated alloy had been exposed to $530 \mathrm{~h}$ of oxidation at $800{ }^{\circ} \mathrm{C}$ and four thermal cycles that involved temperatures ranging between room temperature and $800{ }^{\circ} \mathrm{C}$ [52].

An interesting modification of the composition of the $(\mathrm{Mn}, \mathrm{Co})_{3} \mathrm{O}_{4}$ spinel was presented by Smeacetto et al. [68], who introduced 5 or 10 mass\% of $\mathrm{CuO}$ powder into a $\mathrm{Mn}_{1.5} \mathrm{Co}_{1.5} \mathrm{O}_{4}$ powder suspension during the electrophoretic co-deposition of a layer on the Crofer 22 APU ferritic steel. This made it possible to considerably simplify the technological process used to obtain $\mathrm{Mn}-\mathrm{Co}-\mathrm{Cu}-\mathrm{O}$ spinel coatings, which are characterized by high phase stability, resistance to oxidation at $800{ }^{\circ} \mathrm{C}$ and, moreover, low ASR comparable to that of a layered system 
consisting of steel and a coating based on spinel without any copper addition.

High-chromium ferritic steel designed specifically for interconnects applied in SOECs/SOFCs includes the Crofer $22 \mathrm{H}$ manufactured by Thyssen Krupp VDM GmbH, Germany. This steel had already been evaluated in terms of high-temperature oxidation in various reaction media [73]. However, the majority of performed research focused on the kinetics of the reaction and the elucidation of the oxidation mechanism under isothermal conditions, whereas the actual operating conditions of SOECs involve thermal shocks during the startup of these devices and their emergency shutdown.

In view of the above it seemed justified that subsequent physicochemical investigations of the Crofer $22 \mathrm{H}$ steel with a manganese-cobalt coating with a copper admixture should be conducted with thermal cycling. The presented research was also motivated by the interesting conclusions of previous physicochemical investigations involving the $\mathrm{Mn}_{1.5} \mathrm{Co}_{1.5} \mathrm{O}_{4}$ and $\mathrm{Mn}_{1.45} \mathrm{Co}_{1.45} \mathrm{Fe}_{0.1} \mathrm{O}_{4}$ spinel coatings deposited on the Crofer $22 \mathrm{H}$ via electrophoresis [74]. It was conducted with the intention of gaining practical knowledge concerning the durability of the layered system consisting of the Crofer $22 \mathrm{H}$ steel and an $\mathrm{Mn}_{1.45} \mathrm{Co}_{1.45} \mathrm{Cu}_{0.1} \mathrm{O}_{4}$ coating deposited electrophoretically under thermal cycling conditions, and in particular the suitability of the deposited coating for the surface modification of an interconnect applied in a SOEC. Moreover, the coating material was evaluated in terms of its physicochemical properties via examination conducted for both the corresponding powder and sinter.

\section{Experimental procedure}

\section{Sample preparation}

The Crofer $22 \mathrm{H}$ ferritic steel manufactured by Thyssen Krupp VDM GmbH, Germany, was used as the substrate. The chemical composition of this steel is given in Table 1. The samples used for research were rectangular lamellae with dimensions of $2 \times 1 \times 0.05 \mathrm{~cm}$, which had been cut from a steel sheet. Prior to the investigations, the surface of the steel was washed using water with a detergent, and then degreased in acetone by means of an ultrasound cleaner.

The surface of the substrate was coated with spinel with the nominal composition of $\mathrm{Mn}_{1.45} \mathrm{Co}_{1.45} \mathrm{Cu}_{0.1} \mathrm{O}_{4}$ via electrophoretic deposition (EPD). For this purpose, a suspension of ceramic particles was prepared with acetone and isopropanol mixed at a volume ratio of 80:20. Afterwards,
$0.2 \mathrm{~g}$ of $\mathrm{Mn}_{1.45} \mathrm{Co}_{1.45} \mathrm{Cu}_{0.1} \mathrm{O}_{4}$ ceramic powder was added to the obtained mixture together with $20 \mathrm{~cm}^{3}$ of the solvent and $0.01 \mathrm{~g}$ of iodine. The beaker with the colloidal suspension was cleaned ultrasonically for $15 \mathrm{~min}$ to allow the agglomerates to be broken down and homogenized before electrophoresis was applied to deposit the particles.

During the deposition of particles via cataphoresis, the electrodes were placed ca. $10 \mathrm{~mm}$ from one another; the deposition time was $30 \mathrm{~s}$, and the applied voltage was $60 \mathrm{~V}$. After EPD had finished, the layered steel/coating samples were dried in laboratory air at $80^{\circ} \mathrm{C}$ for $10 \mathrm{~h}$. The experimental setup used to perform EPD consisted of a test bench equipped with a PLH250 DC power supply (peak parameters: $250 \mathrm{~V}, 0.375 \mathrm{~A}$ ).

The heating process applied to give the coatings the desired density involved two stages:

- Stage 1: $2 \mathrm{~h}$ of heating in an $\mathrm{Ar}-\mathrm{H}_{2}$ gas mixture (Ar: $\mathrm{H}$ ratio of 9:1) at $900{ }^{\circ} \mathrm{C}$,

- Stage 2: $4 \mathrm{~h}$ of heating in air at $900{ }^{\circ} \mathrm{C}$.

An uncoated Crofer $22 \mathrm{H}$ sample served as the reference after undergoing the exact same thermal treatment.

As mentioned, a fine $\mathrm{Mn}_{1.45} \mathrm{Co}_{1.45} \mathrm{Cu}_{0.1} \mathrm{O}_{4}$ powder was used to prepare a suspension of ceramic particles for EPD. The same powder was also used to prepare dense sinters. It had been synthesized using EDTA gel processes, in which ethylenediaminetetraacetic acid (EDTA) serves as an agent that complexes metal cations in an aqueous solution. A detailed description of the applied powder preparation procedure can be found in [28].

The preparation of the sinters involved a number of steps, including the calcination of the $\mathrm{Mn}_{1.45} \mathrm{Co}_{1.45} \mathrm{Cu}_{0.1} \mathrm{O}_{4}$ powder in air at $800{ }^{\circ} \mathrm{C}(10 \mathrm{~h})$, milling in anhydrous ethanol with a 3 mass\% admixture of oleic acid in a rotary-vibrational mill, drying at room temperature, and the formation of green bodies with the use of preliminary biaxial pressing under $100 \mathrm{MPa}$ and isostatic pressing under $250 \mathrm{MPa}$. The last stage was the free sintering of the green bodies for $2 \mathrm{~h}$ in air at $1150{ }^{\circ} \mathrm{C}$. The obtained pellets were $10 \mathrm{~mm}$ in diameter and had a thickness of 2 to $3 \mathrm{~mm}$.

\section{Instrumentation}

The NETZSCH STA 449 F3 apparatus was used to perform combined DTA/TG thermal analyses of the precursor gels. This study was carried out in air heated at the rate of
Table 1 Chemical composition of the Crofer $22 \mathrm{H}$ ferritic steel

\begin{tabular}{|c|c|c|c|c|c|c|c|c|c|c|c|}
\hline \multicolumn{12}{|c|}{ Chemical composition/mass $\%$} \\
\hline $\mathrm{Fe}$ & $\mathrm{Cr}$ & Mn & $\mathrm{Si}$ & $\mathrm{Ni}$ & $\mathrm{Al}$ & $\mathrm{C}$ & $\mathrm{P}$ & $\mathrm{Ti}$ & $\mathrm{La}$ & $\mathrm{Nb}$ & $\mathrm{W}$ \\
\hline Ball & 24.0 & 0.8 & 0.6 & 0.5 & 0.1 & 0.03 & 0.05 & 0.2 & 0.2 & 1.0 & 3.0 \\
\hline
\end{tabular}


$10{ }^{\circ} \mathrm{C} \mathrm{min}-1$, over the range of $25-1050{ }^{\circ} \mathrm{C}$, with alumina as the reference.

The WDXRF Axios mAX spectrometer with an Rh lamp and an output of $4 \mathrm{~kW}$ (PANalytical) was used for the XRF study of the powders, performed to determine their chemical composition.

The phase analysis of the powders and coatings was performed with the use of the Bruker D8 Advanced XRD diffractometer, with $\mathrm{CuK}_{\alpha}$ radiation and at a scan rate of $0.02^{\circ}$ per step. XRD patterns were also recorded for the sintered pellets by means of an MTC-High temp direct heating stage with a PtRh strip heater. The samples were heated at a rate of $0.5{ }^{\circ} \mathrm{C} \mathrm{min}{ }^{-1}$ until they reached the selected temperature; this temperature was then maintained for $30 \mathrm{~min}$, allowing the conditions to stabilize. The $2 \theta$ configuration for the measurements was a standard one (step: $0.02^{\circ}$, time per step: $2 \mathrm{~s}$, detector: LynxEye), and the temperature range over which they were performed was $200-800{ }^{\circ} \mathrm{C}$. Qualitative investigations of the phase composition were carried out by means of the HighScore Plus software (PANalytical), the $\mathrm{X}$ 'Pert diffractometer, and the standard data set of PCPDFWIN v.2.3. Rietveld profile refinement with a built-in program module of the HighScore Plus software was applied to determine the unit cell parameters of the constituent phases. The Scherrer equation was used to calculate the average crystallite size for the powder based on the XRD data [75].

The morphology and chemical composition of the samples were examined using a scanning electron microscope (FEI Nova NanoSEM 200) coupled with an EDAX Genesis XM X-ray microanalysis system based on the EDAX Sapphire $\mathrm{Si}(\mathrm{Li}) \mathrm{EDS}$ detector.

The samples were oxidized via exposition to a temperature of either 750 or $800{ }^{\circ} \mathrm{C}$ in a horizontal tube furnace. Three alundum crucibles with samples were placed in a quartz boat, which was then inserted into the furnace. The atmosphere used for the oxidation study was laboratory air; temperature cycling was achieved via the application of 25 cycles, each of which was $48 \mathrm{~h}$ in duration. The total oxidation time was $1200 \mathrm{~h}$. The experimental setup used for sample oxidation had been described in [74]. Another component of the experimental setup was an electronically controlled, mechanized stage, which made it possible to adjust the position of the furnace in two directions relative to the sample holder, after pre-programmed heating and cooling periods. The samples were allowed to cool down to the ambient temperature between the applied 48-h heating cycles. After this temperature had been reached, another heating-cooling cycle started.

After each heating-cooling cycle, the samples and the crucibles were weighed by means of the Radwag XA 210 analytical balance. The net mass of the samples, the spall mass of scales in the crucible, and the sum of the former and the latter, were each determined with an accuracy of
$1.0 \times 10^{-5}$. This made it possible to track the changes in mass due to oxidation; these changes were calculated from the following formulae [26]:

(a) net mass change $(N)$ :

$N=\frac{m_{\mathrm{ni}}-m_{\mathrm{no}}}{A}$

where $m_{\mathrm{ni}}$ - mass of the sample after heating-cooling cycle $i / \mathrm{g}, m_{\mathrm{no}}-$ mass of the sample before this heating-cooling cycle/g and $A$ - surface area of the sample $/ \mathrm{cm}^{2}$,

(b) gross mass change $(G)$ :

$G=\frac{m_{\mathrm{gi}}-m_{\mathrm{go}}}{A}$

where: $m_{\mathrm{gi}}-$ total mass of the sample and crucible after heating-cooling cycle $i / g$ and $m_{\mathrm{go}}-$ total mass of the sample and crucible before this heating-cooling cycle/g,

(c) spall mass change $(S)$ :

$S=G-N$

The rate at which chromium evaporates from the studied samples was measured using an apparatus with a design proposed by Kurokawa et al. [76]. These measurements were conducted in a flowing air- $\mathrm{H}_{2} \mathrm{O}$ $\left(\mathrm{p}\left(\mathrm{H}_{2} \mathrm{O}\right)=9.72 \times 10^{-2} \mathrm{~atm}\right)$ gas mixture at either 750 or $800{ }^{\circ} \mathrm{C}$, for $72 \mathrm{~h}$, under conditions in which the flow rate of the carrier gas was independent from the mass of chromium, i.e. in the unsaturation zone $[77,78]$. These requirements are met by gas flow rates of 95 and $120 \mathrm{~cm}^{3} \mathrm{~min}^{-1}$ for 750 and $800{ }^{\circ} \mathrm{C}$, respectively. A detailed description of the experimental setup used for the measurement of the $\mathrm{Cr}$ evaporation rate and the initial tests aimed at establishing the dependence between the mass of chromium evolved during the evaporation of pure chromia and the flow rate of carrier gas is given in [77, 78]. The measurements of the evaporation rate of $\mathrm{Cr}$ were performed for unmodified Crofer $22 \mathrm{H}$ steel as well as the Crofer $22 \mathrm{H} / \mathrm{Mn}_{1.5} \mathrm{Co}_{1.5} \mathrm{O}_{4}$ and Crofer $22 \mathrm{H} / \mathrm{Mn}_{1.45} \mathrm{Co}_{1.45} \mathrm{Cu}_{0.1} \mathrm{O}_{4}$ layered systems; each of these materials underwent $1200 \mathrm{~h}$ of cyclic oxidation in air at 750 and $800{ }^{\circ} \mathrm{C}$, which yielded a total of six samples. Cr content was determined by means of ICP-OES (OPTIMA 7300 DV, Perkin Elmer). The accuracy of this determination was $2 \%$.

The DC 2-probe, 4-point method with an external source of current was applied to measure the electrical resistance of the studied sample and the coating/steel systems over the temperature range of $35-800{ }^{\circ} \mathrm{C}$. This was performed in laboratory air and with a $0.01 \mathrm{~A}$ current. The preparation of the samples for these measurements, the applied apparatus, and the ASR measurement procedure are described in [79].

The electrical resistance of an oxidized coating/ steel layered system is usually measured in terms of its 
area-specific resistance (ASR), since the exact thickness of an oxide formed on a metallic surface might prove difficult to determine. The ASR of the studied samples was therefore calculated based on the obtained resistance values using the formula:

$\mathrm{ASR}=\frac{R \cdot A}{2}$

where: $R$ - electrical resistance $/ \Omega$ and $A$ - surface area of the Pt layer $/ \mathrm{cm}^{2}$.

Electrical conductivity was also determined for the sinters based on the obtained electrical resistance values and the dimensions of the sinter. The following dependence was used for this purpose:

$\sigma=\frac{L}{S \cdot R}$

where: $R$ - electrical resistance/ $\Omega, S$ - cross-sectional surface area $/ \mathrm{cm}^{2}$ and $L$ - sample thickness $/ \mathrm{cm}^{1}$.

\section{Results and discussion}

\section{Physicochemical characteristics of the gel precursor}

The Mn-Co-Cu gel obtained using EDTA gel processes underwent thermal analyses (DTA/TG); the optimal conditions for the thermal decomposition of this gel via calcination were thus determined, yielding fully reacted powders with the desired characteristics (phase composition, chemical composition, fine-crystalline structure).

The DTA and TG curves that were recorded for the $\mathrm{Mn}-\mathrm{Co}-\mathrm{Cu}$ gel over the range of $25-1050{ }^{\circ} \mathrm{C}$ are shown in Fig. 1. The shape of the TG curve for the $\mathrm{Mn}-\mathrm{Co}-\mathrm{Cu}$ sample suggests a four-stage decomposition process accompanied by exothermal reactions indicated by the DTA curve. Another range in which a loss of mass (ca. 30\% of initial mass) was observed was $200-240{ }^{\circ} \mathrm{C}$; in this case, it can be attributed to the removal of water of crystallization. The total mass loss was ca. $85 \% ; 40 \%$ of the initial mass was lost over the range of $245-320^{\circ} \mathrm{C}$, with one noticeable exothermal effect. This was attributed to the combustion of the gel's organic matrix.

These results suggest that the prerequisite for the total calcination of the gel precursor is a temperature of at least $350{ }^{\circ} \mathrm{C}$. However, research that had also taken into account the impact of calcination temperature on the crystal structure of the products of gel decomposition (for the relevant results, see [45]) had proven that the optimal temperature for the formation of a spinel phase with a cubic structure is $800{ }^{\circ} \mathrm{C}$.

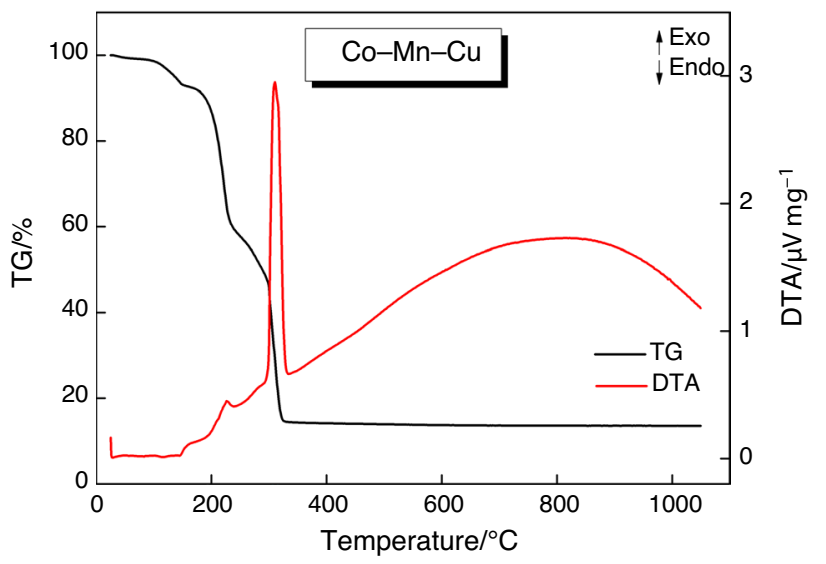

Fig. 1 DTA and TG curves recorded for an $\mathrm{Mn}-\mathrm{Co}-\mathrm{Cu}$ gel obtained via EDTA gel processes

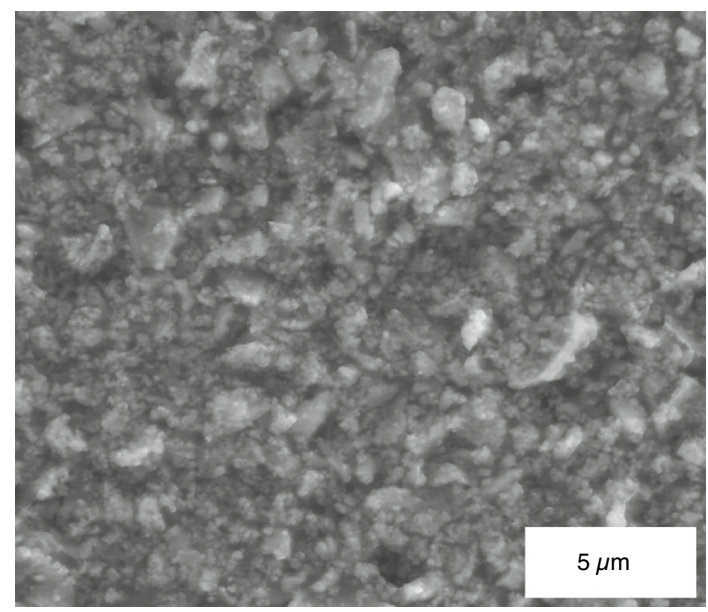

Fig. 2 SEM micrograph of $\mathrm{Mn}_{1.45} \mathrm{Co}_{1.45} \mathrm{Cu}_{0.1} \mathrm{O}_{4}$ powder obtained after calcination $\left(800^{\circ} \mathrm{C} / 10 \mathrm{~h} /\right.$ air); magnification of $10,000 \times$

\section{Physicochemical properties of the powder}

\section{Morphology}

Figure 2 shows an SEM micrograph of the investigated $\mathrm{Mn}_{1.45} \mathrm{Co}_{1.45} \mathrm{Cu}_{0.1} \mathrm{O}_{4}$ powder, obtained after $10 \mathrm{~h}$ of calcination in air at $800{ }^{\circ} \mathrm{C}$.

As determined during the SEM examination, the studied powder had irregular grains with a tendency to form compact agglomerates; these agglomerates consisted of multiple grain clusters that ranged from ca. $0.2 \mu \mathrm{m}$ to about $0.6 \mu \mathrm{m}$ in size. 


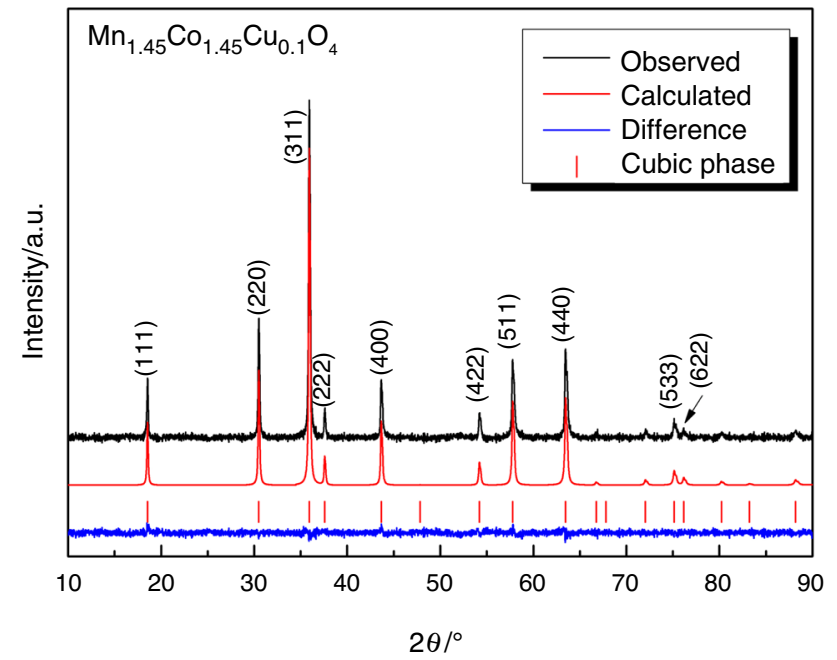

Fig. 3 XRD pattern recorded for an $\mathrm{Mn}_{1.45} \mathrm{Co}_{1.45} \mathrm{Cu}_{0.1} \mathrm{O}_{4}$ powder obtained after $10 \mathrm{~h}$ of calcination in air at $800{ }^{\circ} \mathrm{C}$

\section{Phase and chemical composition}

Figure 3 shows the XRD pattern recorded for the investigated $\mathrm{Mn}_{1.45} \mathrm{Co}_{1.45} \mathrm{Cu}_{0.1} \mathrm{O}_{4}$ powder after calcination. The analysis of the phase composition of the manganese-cobalt spinel with a copper addition of $0.1 \mathrm{~mol} \%$ indicated the sole presence of a cubic phase with a lattice parameter of $a=8.28454 \AA$, whereas unmodified powder with the composition of $\mathrm{Mn}_{1.5} \mathrm{Co}_{1.5} \mathrm{O}_{4}$, obtained using the same method and subjected to the same thermal treatment, is a dual-phase spinel consisting of the $\mathrm{Mn}_{2} \mathrm{CoO}_{4}$ tetragonal phase and the $\mathrm{MnCo}_{2} \mathrm{O}_{4}$ cubic phase [74]. The addition of copper therefore leads to the stabilization of the cubic phase at room temperature. This phase was identified using the ICDD card no. 23-1237. It should be emphasized that this result is consistent with the reports published by other authors [80, 81].

The crystallite size of the $\mathrm{Mn}_{1.45} \mathrm{Co}_{1.45} \mathrm{Cu}_{0.1} \mathrm{O}_{4}$ powder was estimated to be $99 \mathrm{~nm}$ based on the Scherrer dependence [75], which is quite considerable compared to the value of $21 \mathrm{~nm}$, reported for the dual-phase $\mathrm{Mn}_{1.5} \mathrm{Co}_{1.5} \mathrm{O}_{4}$ spinel in [74]. This indicates that the investigated powder was highly sinterable, as manifested by the increased grain size of the cubic phase (Fig. 2).

The degree to which the $\mathrm{Mn}_{1.45} \mathrm{Co}_{1.45} \mathrm{Cu}_{0.1} \mathrm{O}_{4}$ powder obtained after $10 \mathrm{~h}$ of calcination in air at $800{ }^{\circ} \mathrm{C}$ deviated from its stoichiometric composition was determined by means of XRF. The $\mathrm{Mn}: \mathrm{Co}: \mathrm{Cu}$ ion molar ratio was 1.46:1.43:0.11, which approximately corresponded to the nominal composition.

The conducted analysis indicates that the EDTA gel processes can be combined with the appropriate thermal treatment and applied to obtain fully reacted powder with the desired chemical composition.

\section{Physicochemical properties of the sinter}

\section{Morphology}

Figure 4 shows the SEM micrographs of the cross section of the $\mathrm{Mn}_{1.45} \mathrm{Co}_{1.45} \mathrm{Cu}_{0.1} \mathrm{O}_{4}$ sinter obtained from a powder synthesized using EDTA gel processes and thermally treated for $2 \mathrm{~h}$ in air at $1150{ }^{\circ} \mathrm{C}$. The studied sinter was compact and exhibited a degree of porosity. Its relative density was $92.4 \%$, which corresponds to a porosity of $7.6 \%$. The sample was characterized by coarse grains in the form of connected lamellae (inset: Fig. 4). The size of these grains varied from ca. 5 to around $30 \mu \mathrm{m}$. When comparing the sample's morphology with that of the $\mathrm{Mn}_{1.5} \mathrm{Co}_{1.5} \mathrm{O}_{4}$ sinter [74], it is evident that the $\mathrm{Mn}_{1.45} \mathrm{Co}_{1.45} \mathrm{Cu}_{0.1} \mathrm{O}_{4}$ sinter had much larger grains due to its copper content, since the presence of this element favours crystallite growth during high-temperature thermal treatment.

\section{Phase composition}

In order to study the structural changes which the spinel sinter might have undergone as a result of exposure to high temperatures, XRD investigations were performed at room temperature and over the temperature range of $200-800{ }^{\circ} \mathrm{C}$.

Figure 5 shows a series of XRD patterns recorded for the $\mathrm{Mn}_{1.45} \mathrm{Co}_{1.45} \mathrm{Cu}_{0.1} \mathrm{O}_{4}$ sinter thermally treated in air at $1150{ }^{\circ} \mathrm{C}$ for $2 \mathrm{~h}$. The XRD spectra after a numerical Rietveld analysis run using the $\mathrm{X}$ 'Pert Plus software indicate the presence of a single phase only, namely the $\mathrm{MnCo}_{2} \mathrm{O}_{4}$ cubic phase with the $\mathrm{F} d \overline{3} m$ space group, as per the ICDD card no. 23-1237. Additionally, the reflections from the alumina substrate are also visible. It is worth noting that the phase composition of heated samples did not change over

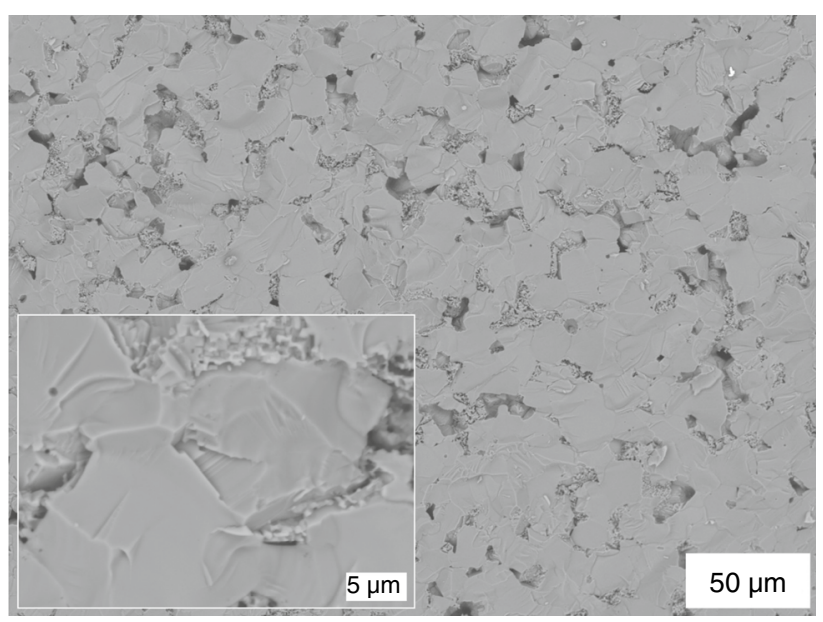

Fig. 4 SEM micrograph of an $\mathrm{Mn}_{1.45} \mathrm{Co}_{1.45} \mathrm{Cu}_{0.1} \mathrm{O}_{4}$ sinter after thermal treatment $\left(1150{ }^{\circ} \mathrm{C} / 2 \mathrm{~h} /\right.$ air $)$, under a magnification of $500 \times$ and $5000 \times$ (inset) 


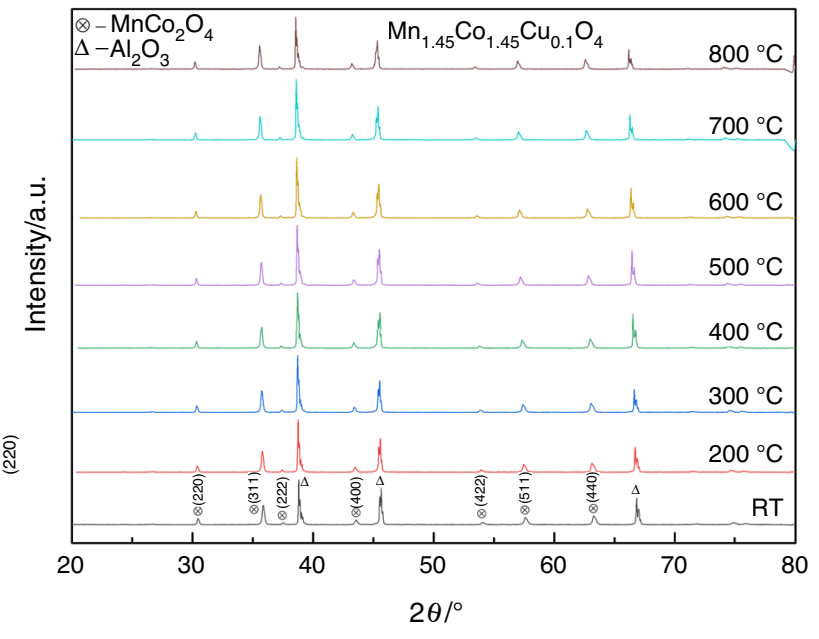

Fig. 5 Diffraction patterns recorded for the $\mathrm{Mn}_{1.45} \mathrm{Co}_{1.45} \mathrm{Cu}_{0.1} \mathrm{O}_{4}$ sinter after $2 \mathrm{~h}$ of thermal treatment in air at $1150{ }^{\circ} \mathrm{C}$

the $200-800{ }^{\circ} \mathrm{C}$ range. The only change observed with the increase in temperature was in the positions of diffraction reflections, which was due to the thermal expansion of the studied material.

It can therefore be expected that at the planned operating temperature of an IT-SOEC, i.e. $800{ }^{\circ} \mathrm{C}$, an interconnect composed of steel modified with a protective-conducting coating with a cubic spinel structure should exhibit a low area-specific resistance (ASR). This is a consequence of the fact that a manganese-cobalt spinel with a cubic structure is characterized by higher electrical conductivity than a spinel with a tetragonal structure $[28,69]$.

Table 2 lists the values of lattice constant $a$ of the cubic phase of the $\mathrm{Mn}_{1.45} \mathrm{Co}_{1.45} \mathrm{Cu}_{0.1} \mathrm{O}_{4}$ sinter investigated by means of XRD over the temperature range of $25-800{ }^{\circ} \mathrm{C}$. Corresponding data for the $\mathrm{Mn}_{1.5} \mathrm{Co}_{1.5} \mathrm{O}_{4}$ sinter are included as a reference [74].

The lattice constants of the $\mathrm{Mn}_{1.45} \mathrm{Co}_{1.45} \mathrm{Cu}_{0.1} \mathrm{O}_{4}$ are clearly lower than those measured for the unmodified sinter $\left(\mathrm{Mn}_{1.5} \mathrm{Co}_{1.5} \mathrm{O}_{4}\right)$ at every single measurement temperature. It is worth emphasizing that both the differences in lattice parameters after $\mathrm{Cu}$ substitution and the associated differences in cation distribution most probably stemmed from thermal treatment conditions. The $\left(\mathrm{Cu}^{+}{ }_{0.65} \mathrm{Mn}^{3+}{ }_{0.35}\right)$ $\left[\mathrm{Cu}^{2+}{ }_{0.35} \mathrm{Co}^{3+} \mathrm{Mn}^{4+}{ }_{0.65}\right] \mathrm{O}^{2-}{ }_{4}$ distribution was suggested by Brabers and Setten [82]. Other authors, in contrast, postulated that tetrahedral sites are occupied by both $\mathrm{Cu}^{2+}$ and $\mathrm{Cu}^{+}$, whereas octahedral sites are occupied by $\mathrm{Co}^{3+}$ and $\mathrm{Mn}^{3+/ 4+}[83,84]$. Talic demonstrated that an increased degree of substitution with $\mathrm{Cu}$ entails improved electrical conductivity and reduced energy of activation [69]. The direct participation of copper ions in charge transfer is indicated by the differences in activation energy. In a spinel structure, small polaron hopping can only occur between
Table 2 Lattice constants of the cubic phase of the $\mathrm{Mn}_{1.45} \mathrm{Co}_{1.45} \mathrm{Cu}_{0.1} \mathrm{O}_{4}$ sinter, as determined via XRD over the temperature range from room temperature to $800^{\circ} \mathrm{C}$, as compared to data for the $\mathrm{Mn}_{1.5} \mathrm{Co}_{1.5} \mathrm{O}_{4}$ sinter, reported in [74]

\begin{tabular}{lll}
\hline $\begin{array}{l}\text { Measurement tempera- } \\
\text { ture }(\mathrm{XRD}) /{ }^{\circ} \mathrm{C}\end{array}$ & Sinter \\
\cline { 2 - 3 } & $\mathrm{Mn}_{1.5} \mathrm{Co}_{1.5} \mathrm{O}_{4}[74]$ & $\mathrm{Mn}_{1.45} \mathrm{Co}_{1.45} \mathrm{Cu}_{0.1} \mathrm{O}_{4}$ \\
\cline { 2 - 2 } $\mathrm{RT}$ & \multicolumn{2}{l}{ Lattice constant/nm } \\
\cline { 2 - 3 } & $0.83331(1)$ & $0.82978(6)$ \\
\hline 200 & $0.83471(1)$ & $0.83137(8)$ \\
300 & $0.83567(2)$ & $0.83257(2)$ \\
400 & $0.83648(2)$ & $0.83316(9)$ \\
500 & $0.83731(3)$ & $0.83439(7)$ \\
700 & $0.83807(2)$ & $0.83519(3)$ \\
800 & $0.83897(1)$ & $0.83638(6)$ \\
\hline
\end{tabular}

equivalent sites. Since the cation-cation distance between octahedral sites is the shortest, both $\mathrm{Cu}^{+}$and $\mathrm{Cu}^{2+}$ can be inferred to occupy this type of sites [51].

When concluding this section, it is worth adding that the thermal expansion coefficient of the $\mathrm{Mn}_{1.45} \mathrm{Co}_{1.45} \mathrm{Cu}_{0.1} \mathrm{O}_{4}$ sinter, determined from a linear plot representing parameter $a$ as a function of temperature, obtained based on the results presented in Fig. 5, was equal to $11.9 \times 10^{-6} / \mathrm{K}^{-1}$. What is very significant, this value was highly consistent with the thermal expansion coefficient of the Crofer $22 \mathrm{H}$ ferritic steel, which has a value of $11.8 \times 10^{-6} / \mathrm{K}^{-1}$ over the temperature range of $20-800{ }^{\circ} \mathrm{C}$ [85].

\section{Electrical conductivity}

Figure 6 illustrates the Arrhenius dependence of electrical conductivity on temperature for the $\mathrm{Mn}_{1.45} \mathrm{Co}_{1.45} \mathrm{Cu}_{0.1} \mathrm{O}_{4}$ sinter investigated in the present study and the $\mathrm{Mn}_{1.5} \mathrm{Co}_{1.5} \mathrm{O}_{4}$ reference sinter [74]. Electrical resistance was found to decrease with increasing temperature in the case of both sinters, which indicates a thermally activated increase in electrical conductivity.

The $\mathrm{Mn}_{1.45} \mathrm{Co}_{1.45} \mathrm{Cu}_{0.1} \mathrm{O}_{4}$ sinter was characterized by higher electrical conductivity than the spinel which had not undergone chemical modification $\left(\mathrm{Mn}_{1.5} \mathrm{Co}_{1.5} \mathrm{O}_{4}\right)$ across the entire investigated range of temperature. At $900{ }^{\circ} \mathrm{C}$, the electrical conductivity of the sinter containing copper was 48 $\mathrm{S} \mathrm{cm}^{-1}$, whereas that of the $\mathrm{Mn}_{1.5} \mathrm{Co}_{1.5} \mathrm{O}_{4}$ sinter was equal to $30 \mathrm{~S} \mathrm{~cm}^{-1}$ [74]. It is worth noting that these values are significantly higher than the electrical conductivity of both chromia $\left(4.6 \times 10^{-3} \mathrm{~S} \mathrm{~cm}^{-1}\right)$ [77] and the $\mathrm{MnCr}_{2} \mathrm{O}_{4}$ spinel $\left(1.9 \times 10^{-2} \mathrm{~S} \mathrm{~cm}^{-1}\right)$ [77], the main constituents of the scale that forms on high-chromium ferritic steel after oxidation at temperatures of the order of $800{ }^{\circ} \mathrm{C}$ [9-14]. 


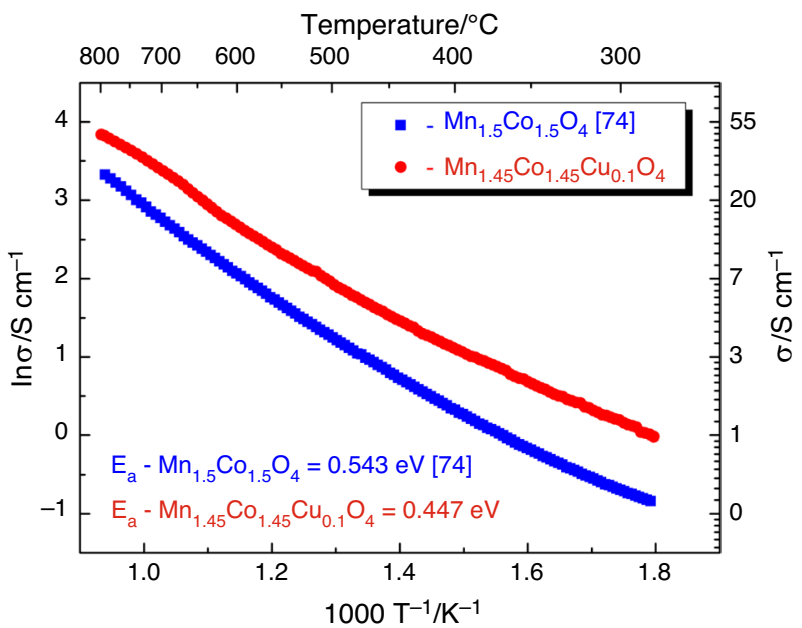

Fig. 6 Arrhenius plot showing the dependence of the electrical conductivity of the investigated $\mathrm{Mn}_{1.45} \mathrm{Co}_{1.45} \mathrm{Cu}_{0.1} \mathrm{O}_{4}$ sinter and an unmodified $\mathrm{Mn}_{1.5} \mathrm{Co}_{1.5} \mathrm{O}_{4}$ sinter [74]

The following Arrhenius dependence was used to calculate the activation energy of electrical conductivity [11]:

$\sigma=\left(\frac{\sigma_{\mathrm{o}}}{T}\right) \exp \left(\frac{-E_{\mathrm{a}}}{k T}\right)$

where: $\sigma$ - conductivity of the sample/ $\Omega^{-1} \mathrm{~cm}^{-1}, \sigma_{\mathrm{o}}$ - preexponential factor $/ \Omega^{-1} \mathrm{~cm}^{-1} \mathrm{~K}^{-1}, \mathrm{E}_{\mathrm{a}}$ - activation energy/ $\mathrm{eV}, \mathrm{k}-$ Boltzmann constant/eV $\mathrm{K}^{-1}$ and $T$ - absolute temperature/K.

In the case of the $\mathrm{Mn}_{1.45} \mathrm{Co}_{1.45} \mathrm{Cu}_{0.1} \mathrm{O}_{4}$ sinter, the activation energy $\left(\mathrm{E}_{\mathrm{a}}\right)$ for the temperature range of $280-800{ }^{\circ} \mathrm{C}$ was $0.447 \mathrm{eV}$, which was lower than the values reported for $\mathrm{Mn}_{1.5} \mathrm{Co}_{1.5} \mathrm{O}_{4}(0.543 \mathrm{eV})$ [74] and $\mathrm{Mn}_{1.45} \mathrm{Co}_{1.45} \mathrm{Fe}_{0.1} \mathrm{O}_{4}$ $(0.502 \mathrm{eV})$ [74]. The activation energy estimated for the studied sinter was also slightly lower than the activation energy of a sinter with the composition of $\mathrm{MnCo}_{1.9} \mathrm{Cu}_{0.1} \mathrm{O}_{4}$, reported to be $0.50 \mathrm{eV}$ [86]. However, the electrical conductivity of the $\mathrm{MnCo}_{1.9} \mathrm{Cu}_{0.1} \mathrm{O}_{4}$ sample obtained in the above-cited paper was more than twice as high as that of $\mathrm{Mn}_{1.45} \mathrm{Co}_{1.45} \mathrm{Cu}_{0.1} \mathrm{O}_{4}$ due to the significantly higher cobalt content in the former.

Based on the literature data reported for a number of spinels with compositions of $\mathrm{Cu}_{\mathrm{x}} \mathrm{Mn}_{3-\mathrm{x}} \mathrm{O}_{4}(1.1<x<1.6)$, $\mathrm{Mn}_{1+\mathrm{x}} \mathrm{Cr}_{2-\mathrm{x}} \mathrm{O}_{4}(0 \leq x \leq 1), \mathrm{NiMn}_{2} \mathrm{O}_{4}, \mathrm{Mn}_{\mathrm{x}} \mathrm{Fe}_{3-\mathrm{x}} \mathrm{O}_{4}(\mathrm{x}>2.6)$ and $\mathrm{Mn}_{3} \mathrm{O}_{4}$ [87, 88], it can be presumed that the underlying mechanism of electrical conductivity in the sinter studied in the present paper is small polaron hopping. The most recent research on the subject $[89,90]$ suggests that small polaron hopping may result from the presence of $\mathrm{Co}^{2+} / \mathrm{Co}^{\mathrm{III}}$ and $\mathrm{Mn}^{3+} / \mathrm{Mn}^{4+}$ couples at octahedral sites. The presence of cations with different valence at octahedral positions may therefore lead to the increased electrical conductivity of the aforementioned spinels [90].

\section{Physicochemical properties of the coating/steel systems}

\section{Oxidation kinetics}

To evaluate the oxidation resistance of the Crofer $22 \mathrm{H}$ ferritic steel which had its surface modified with an active $\mathrm{Mn}_{1.45} \mathrm{Co}_{1.45} \mathrm{Cu}_{0.1} \mathrm{O}_{4}$ spinel coating, the kinetics of oxidation of the Crofer $22 \mathrm{H} / \mathrm{Mn}_{1.45} \mathrm{Co}_{1.45} \mathrm{Cu}_{0.1} \mathrm{O}_{4}$ layered system were determined over a total time of $1200 \mathrm{~h}$, in 25 cycles of $48 \mathrm{~h}$, with temperature cycling, for oxidation temperatures of 750 and $800{ }^{\circ} \mathrm{C}$, and in an air atmosphere. This also provided significant information regarding the adhesion of the coating to the steel substrate.

The oxidation kinetics were measured using gravimetry. Changes in net mass $(N)$, the spall mass of the coating and/or scale in the crucible $(S)$, and gross mass $(G)$ were determined as a function of time, based on Eqs. (1)-(3). They are shown separately for the two applied oxidation temperatures $\left(750{ }^{\circ} \mathrm{C}-\right.$ Fig. $7 \mathrm{a}, 800{ }^{\circ} \mathrm{C}-$ Fig. $\left.7 \mathrm{~b}\right)$.

The proportion of the mass of the oxidation products collected in the crucible to the total mass of the oxidation products formed on the coating was very low in the case of both 750 and $800{ }^{\circ} \mathrm{C}$. This proves that the $\mathrm{Mn}_{1.45} \mathrm{Co}_{1.45} \mathrm{Cu}_{0.1} \mathrm{O}_{4}$ coating exhibited very strong adhesion to the steel substrate, which is especially evident when these results are compared with those obtained for unmodified Crofer $22 \mathrm{H}$ steel oxidized under the same conditions [74]. It should moreover be emphasized that the investigated coating and the $\mathrm{Mn}_{1.5} \mathrm{Co}_{1.5} \mathrm{O}_{4}$ coating exhibit similar protective properties [74].

Figure 8 shows curves that represent the kinetics of cyclic oxidation of the Crofer $22 \mathrm{H} / \mathrm{Mn}_{1.45} \mathrm{Co}_{1.45} \mathrm{Cu}_{0.1} \mathrm{O}_{4}$ layered system as well the reference samples (Crofer 22 $\mathrm{H} / \mathrm{Mn}_{1.5} \mathrm{Co}_{1.5} \mathrm{O}_{4}$ [74] and unmodified Crofer $22 \mathrm{H}$ ferritic steel [74]), recorded over $1200 \mathrm{~h}$ of oxidation in air at $750{ }^{\circ} \mathrm{C}$ (Fig. 8a) and $800{ }^{\circ} \mathrm{C}$ (Fig. 8b), expressed as the square of the net mass change per unit area in a function of reaction time. It should be emphasized that the curves in Fig. 8 are not adjusted for the formation of volatile chromium compounds. For reaction times shorter than $1200 \mathrm{~h}$, the relative error due to not taking this process into account is below $3 \%$.

As these plots show, the mass gain of the oxidation product formed for the investigated sample during cyclic oxidation approximately obeys the parabolic rate law-as in the case of the reference samples [74]—and can be represented using the Pilling-Bedworth equation [91]: 
(a)

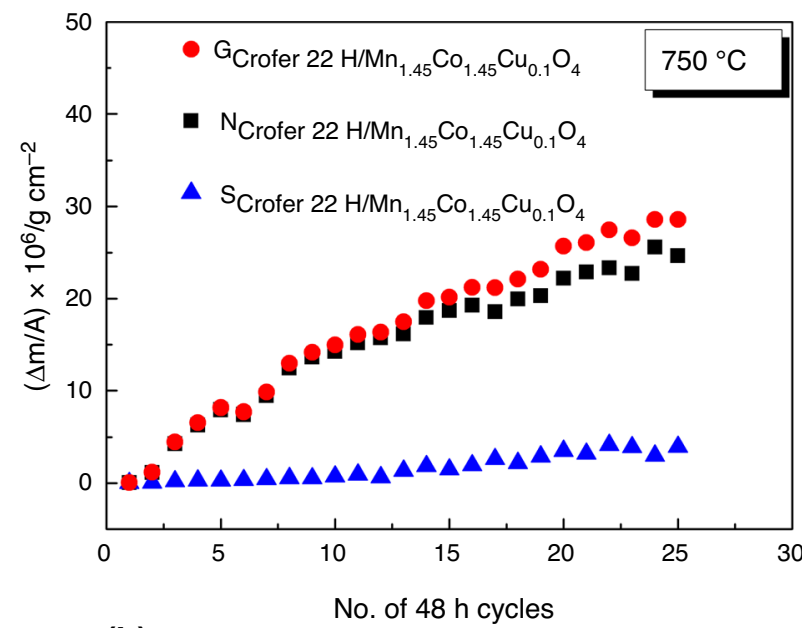

(b)

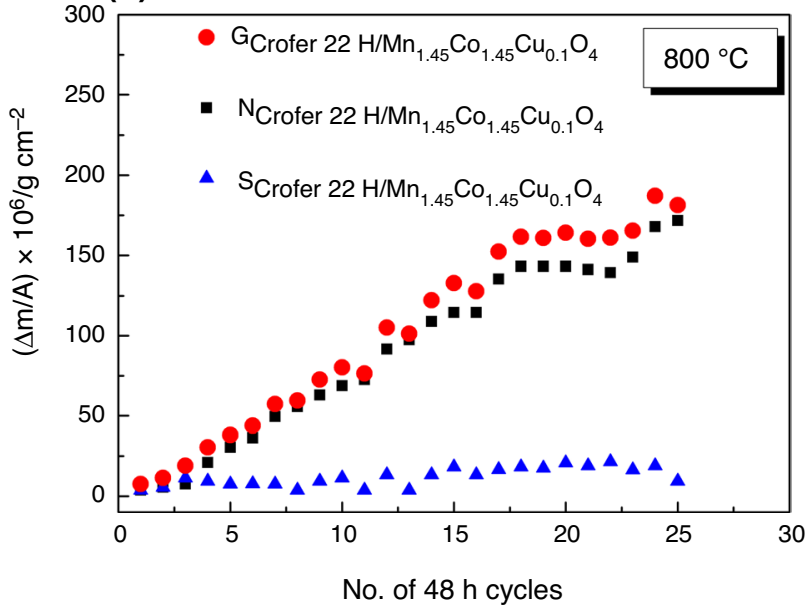

Fig. 7 Net mass of the sample, spall mass, and gross mass over $1200 \mathrm{~h}$ of cyclic oxidation of the Crofer $22 \mathrm{H} / \mathrm{Mn}_{1.45} \mathrm{Co}_{1.45} \mathrm{Cu}_{0.1} \mathrm{O}_{4}$ layered system oxidized in air at: $\mathbf{a} 750{ }^{\circ} \mathrm{C}, \mathbf{b} 800{ }^{\circ} \mathrm{C}$

$\left(\frac{\Delta m}{A}\right)^{2}=k_{\mathrm{p}} \cdot t+C$

where: $\Delta \mathrm{m} / \mathrm{A}$ - mass gain per unit area/g cm ${ }^{-2}, k_{\mathrm{p}}-$ parabolic rate constant $/ \mathrm{g}^{2} \mathrm{~cm}^{-4} \mathrm{~s}^{-1}, t$-reaction time/s and $\mathrm{C}$ - integration constant that defines the onset of parabolic kinetics.

Based on this equation, which indicates that the slowest contributing process that determines that oxidation rate of the investigated samples is the diffusion of reagents in the scale and/or the oxidation product, the parabolic rate constants $\left(k_{\mathrm{p}}\right)$ of oxidation at $750{ }^{\circ} \mathrm{C}$ and $800{ }^{\circ} \mathrm{C}$ were determined for the Crofer $22 \mathrm{H} / \mathrm{Mn}_{1.45} \mathrm{Co}_{1.45} \mathrm{Cu}_{0.1} \mathrm{O}_{4}$ layered system by means of the graphical method. The results, including sample oxidation temperature $(T)$, parabolic rate constant $\left(k_{\mathrm{p}}\right)$, correlation coefficients $(r)$ from the regression analysis, and the time intervals $(t)$ in which (a)

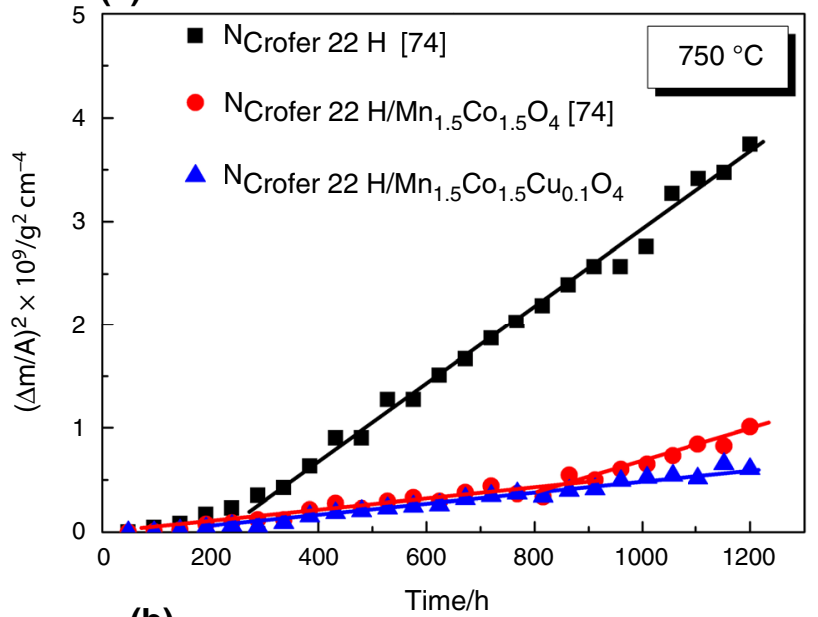

(b)

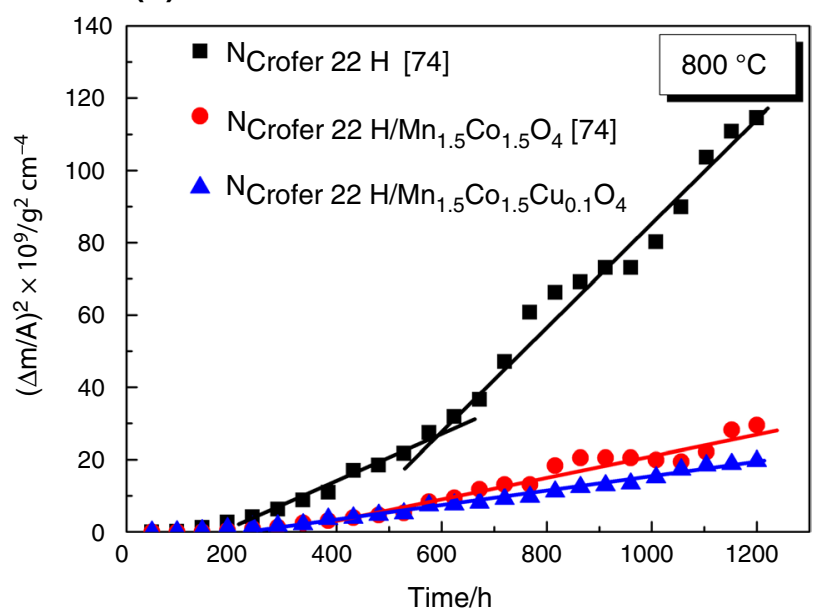

Fig. 8 Parabolic oxidation kinetics of the Crofer $22 \mathrm{H} /$ $\mathrm{Mn}_{1.45} \mathrm{Co}_{1.45} \mathrm{Cu}_{0.1} \mathrm{O}_{4}$ layered system as well as the Crofer $22 \mathrm{H} /$ $\mathrm{Mn}_{1.5} \mathrm{Co}_{1.5} \mathrm{O}_{4}$ [74] and Crofer $22 \mathrm{H}$ [74] reference samples over $1200 \mathrm{~h}$ of cyclic oxidation in air at $\mathbf{a} 750{ }^{\circ} \mathrm{C}$ and $\mathbf{b} 800{ }^{\circ} \mathrm{C}$

the parabolic rate law is obeyed, are collected in Table 3, alongside the data for the reference samples - the unmodified Crofer $22 \mathrm{H} \mathrm{[74]} \mathrm{ferritic} \mathrm{steel} \mathrm{and} \mathrm{the} \mathrm{Crofer} 22 \mathrm{H} /$ $\mathrm{Mn}_{1.5} \mathrm{Co}_{1.5} \mathrm{O}_{4}$ layered system [74].

The data in Fig. 8 and Table 3 show that at $800{ }^{\circ} \mathrm{C}$ the parabolic oxidation rate constant for the Crofer $22 \mathrm{H}$ steel without any coating is higher by ca. half an order of magnitude than that for the steel modified with manganese-cobalt coating $\left(\mathrm{Mn}_{1.5} \mathrm{Co}_{1.5} \mathrm{O}_{4}\right)$ and almost an order of magnitude higher than the rate for the steel with the protective coating based on manganese-cobalt spinel with a copper addition $\left(\mathrm{Mn}_{1.45} \mathrm{Co}_{1.45} \mathrm{Cu}_{0.1} \mathrm{O}_{4}\right)$. A similar relationship between the $k_{\mathrm{p}}$ values is also observed when oxidation is conducted at $750{ }^{\circ} \mathrm{C}$. This means that the layered system consisting of the Crofer $22 \mathrm{H}$ steel coated with $\mathrm{Mn}_{1.45} \mathrm{Co}_{1.45} \mathrm{Cu}_{0.1} \mathrm{O}_{4}$ has the highest resistance to oxidation of all compared types of samples. 
Table 3 Parabolic oxidation rate constants for the Crofer $22 \mathrm{H} / \mathrm{Mn}_{1.45} \mathrm{Co}_{1.45} \mathrm{Cu}_{0.1} \mathrm{O}_{4}$ layered system and the $k_{\mathrm{p}}$ values previously reported for unmodified Crofer $22 \mathrm{H}$ ferritic steel and the Crofer $22 \mathrm{H} /$ $\mathrm{Mn}_{1.5} \mathrm{Co}_{1.5} \mathrm{O}_{4}$ layered system oxidized under corresponding conditions [74]

\begin{tabular}{lllll}
\hline Sample & $T /{ }^{\circ} \mathrm{C}$ & $t / \mathrm{h}$ & $k_{\mathrm{p}} / \mathrm{g}^{2} \mathrm{~cm}^{-4} \mathrm{~s}^{-1}$ & $r$ \\
\hline Crofer 22 H [74] & 750 & $288-1200$ & $1.03 \times 10^{-15}$ & 0.9962 \\
& 800 & $192-624$ & $1.89 \times 10^{-14}$ & 0.9869 \\
Crofer 22 H/Mn ${ }_{1.5} \mathrm{Co}_{1.5} \mathrm{O}_{4}[74]$ & & $576-1200$ & $3.85 \times 10^{-14}$ & 0.9880 \\
& 750 & $48-912$ & $1.66 \times 10^{-16}$ & 0.9676 \\
& & $816-1200$ & $4.20 \times 10^{-16}$ & 0.9714 \\
Crofer 22 H/Mn $\mathrm{Mn}_{1.45} \mathrm{Co}_{1.45} \mathrm{Cu}_{0.1} \mathrm{O}_{4}$ & 750 & $384-1200$ & $8.64 \times 10^{-15}$ & 0.9746 \\
& 800 & $336-1200$ & $5.65 \times 10^{-15}$ & 0.9900 \\
& & & & 0.9937 \\
\hline
\end{tabular}

The parabolic oxidation rate constants for the layered systems investigated in the present study are in the range of values obtained for steels and alloys referred to as "chromia formers", often applied for the construction of metallic interconnects for intermediate-temperature solid oxide fuel cells and solid oxide electrolyzer cells [9-15].

\section{Phase composition, morphology and chemical composition}

Phase composition analyses of the products formed during the cyclic oxidation of the Crofer $22 \mathrm{H} / \mathrm{Mn}_{1.45} \mathrm{Co}_{1.45} \mathrm{Cu}_{0.1} \mathrm{O}_{4}$ samples at 750 and $800{ }^{\circ} \mathrm{C}$, performed by means of X-ray diffraction, revealed the sole presence of cubic manganesecobalt spinel $\left(\mathrm{MnCo}_{2} \mathrm{O}_{4}\right)$ on their surface. According to literature data [74], the oxidation of the Crofer $22 \mathrm{H}$ steel with the $\mathrm{Mn}_{1.5} \mathrm{Co}_{1.5} \mathrm{O}_{4}$ coating under identical conditions leads to the formation of both cubic manganese-cobalt spinel $\left(\mathrm{MnCo}_{2} \mathrm{O}_{4}\right)$, which is predominant, and its tetragonal form $\left(\mathrm{Mn}_{2} \mathrm{CoO}_{4}\right)$ [74]. On the other hand, the scales formed on the unmodified Crofer $22 \mathrm{H}$ steel were composed of chromia $\left(\mathrm{Cr}_{2} \mathrm{O}_{3}\right)$ and the manganese-chromium spinel $\left(\mathrm{MnCr}_{2} \mathrm{O}_{4}\right)$ [74]. It is worth mentioning that the oxidation of both the samples investigated in the present work as well as those studied in [74] was associated with the formation of Laves phase precipitates with the composition of $\mathrm{NbFe}_{2}$.

Figure 9 shows the SEM micrographs of the surface of $\mathrm{Mn}_{1.45} \mathrm{Co}_{1.45} \mathrm{Cu}_{0.1} \mathrm{O}_{4}$ coatings deposited via electrophoretic deposition on a Crofer $22 \mathrm{H}$ steel substrate, oxidized for $1200 \mathrm{~h}$ in air at $750{ }^{\circ} \mathrm{C}$ (Fig. 9a) or $800{ }^{\circ} \mathrm{C}$ (Fig. 9b), with temperature cycling. The SEM images show that the obtained $\mathrm{Mn}_{1.45} \mathrm{Co}_{1.45} \mathrm{Cu}_{0.1} \mathrm{O}_{4}$ coatings are characterized by a certain level of porosity, which is less pronounced for the sample oxidized at $750{ }^{\circ} \mathrm{C}$ (Fig. 9a). Both coatings consist of irregularly shaped agglomerates with size from about 2 to $4 \mu \mathrm{m}$.

Oxidation at $800{ }^{\circ} \mathrm{C}$ is associated with larger grains (Fig. 9b). At certain sites on the analysed coatings, numerous cracks can be seen, with compact areas of cubic $\mathrm{MnCo}_{2} \mathrm{O}_{4}$ between them; this is confirmed by the XRD results. The occurrence of these cracks can be traced to the copper content in the investigated coating; copper makes the
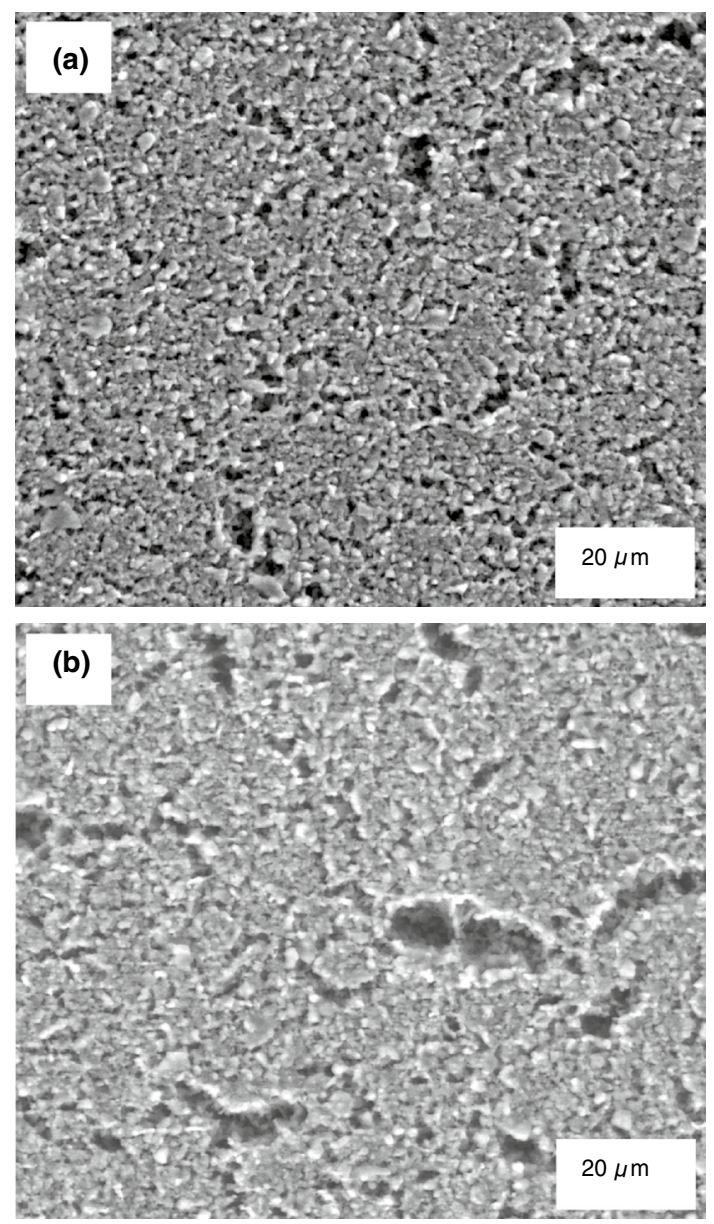

Fig. 9 SEM micrographs of the surface of the $\mathrm{Mn}_{1.45} \mathrm{Co}_{1.45} \mathrm{Cu}_{0.1} \mathrm{O}_{4}$ coating on the Crofer $22 \mathrm{H}$ steel after $1200 \mathrm{~h}$ of cyclic oxidation in air at: a $750{ }^{\circ} \mathrm{C}$ and $\mathbf{b} 800{ }^{\circ} \mathrm{C}$

coating material more sinterable and thereby more shrinkable. This is confirmed by the absence of such cracks in $\mathrm{Mn}_{1.5} \mathrm{Co}_{1.5} \mathrm{O}_{4}$ coatings [74]. On the other hand, the presence of copper is advantageous with regard to the stability of the cubic form of the manganese-cobalt spinel during longterm exposure to high temperatures; the coatings without copper $\left(\mathrm{Mn}_{1.5} \mathrm{Co}_{1.5} \mathrm{O}_{4}\right)$ also contain a certain amount of the 
tetragonal phase [74]. Some research results indicate that the latter phase might adversely affect the electrical conductivity of the investigated steel/coating layered system [28, 69].

Figure 10 shows the SEM micrographs of the cross-sections of Crofer $22 \mathrm{H}$ samples coated with $\mathrm{Mn}_{1.45} \mathrm{Co}_{1.45} \mathrm{Cu}_{0.1} \mathrm{O}_{4}$ and oxidized for $1200 \mathrm{~h}$ in air at $750{ }^{\circ} \mathrm{C}$ (Fig. 10a) or $800{ }^{\circ} \mathrm{C}$ (Fig. 10b), with temperature cycling. As can be seen, the ceramic coatings deposited on this ferritic steel via electrophoresis and thermally treated at either of the investigated temperatures are composed of grains in the form of agglomerates with a size between ca. 0.1 and $2.0 \mu \mathrm{m}$ and-despite a certain level of porosity, especially in the outer part- they exhibit strong adhesion to the metallic core.

Their thickness is ca. $10 \mu \mathrm{m}$ across nearly the entire surface area of the sample. It should be added that the density of these coatings is higher than that of $\mathrm{Mn}_{1.5} \mathrm{Co}_{1.5} \mathrm{O}_{4}$ and $\mathrm{Mn}_{1.45} \mathrm{Co}_{1.45} \mathrm{Fe}_{0.1} \mathrm{O}_{4}$ coatings deposited on the Crofer $22 \mathrm{H}$ and thermally treated under the same conditions [74]. The higher density stems from the presence of copper, which—as
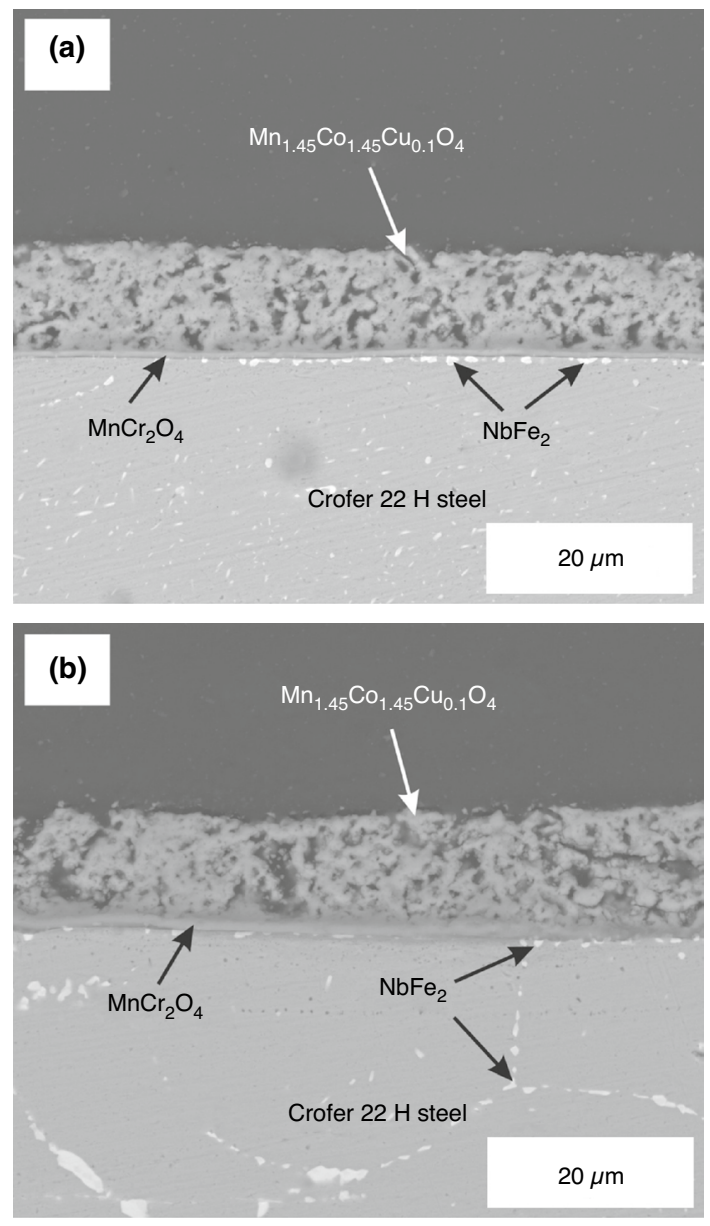

Fig. 10 SEM micrographs showing the polished cross sections of samples of the Crofer $22 \mathrm{H} / \mathrm{Mn}_{1.45} \mathrm{Co}_{1.45} \mathrm{Cu}_{0.1} \mathrm{O}_{4}$ layered system after $1200 \mathrm{~h}$ of cyclic oxidation in air at: a $750{ }^{\circ} \mathrm{C}$ and b $800{ }^{\circ} \mathrm{C}$ mentioned-improves the sinterability of manganese-cobalt spinel. The coating in the steel/coating layered system oxidized at $800{ }^{\circ} \mathrm{C}$ is characterized by cracks and fissures (Fig. 10b), since the amplitude of thermal stress generated in this case exceeds its tensile strength. The analysis of sample morphology and chemical composition conducted for the two steel/coating layered systems $\left(750 / 800^{\circ} \mathrm{C}\right)$ via SEM-EDS revealed the presence of a continuous intermediate reaction layer between the $\mathrm{Mn}_{1.45} \mathrm{Co}_{1.45} \mathrm{Cu}_{0.1} \mathrm{O}_{4}$ coating and the Crofer $22 \mathrm{H}$ substrate. The thickness of these layers is 0.4 and $1.2 \mu \mathrm{m}$ for 750 and $800{ }^{\circ} \mathrm{C}$, respectively; these values are significantly lower than those observed in the case of scales formed on unmodified Crofer $22 \mathrm{H}$ steel (2.1 and $3.7 \mu \mathrm{m}$ for 750 and $800{ }^{\circ} \mathrm{C}$, respectively [74]). The ceramic coating prepared as described in the present study may therefore play the role of a protective barrier that reduces the rate of oxidation in air at temperatures that vary periodically. In the case of both samples, bright precipitates in the form of the $\mathrm{NbFe}_{2}$ phase are observed at the steel/coating interface and along grain boundaries in the steel (Fig. 10a, b).

Figure 11 shows an SEM micrograph of the cross-section of the Crofer $22 \mathrm{H} / \mathrm{Mn}_{1.45} \mathrm{Co}_{1.45} \mathrm{Cu}_{0.1} \mathrm{O}_{4}$ layered system obtained after $1200 \mathrm{~h}$ of cyclic oxidation in air at $750{ }^{\circ} \mathrm{C}$ as well as the EDS point analysis spectra recorded for areas marked "1", "2", "3" and "4" in the micrograph.

EDS point analysis for an area within the intermediate reaction layer revealed the presence of the $\mathrm{MnCr}_{2} \mathrm{O}_{4}$ manganese-chromium spinel (Fig. 11 - area "2"). The EDS spectrum recorded for the upper part of the coating (Fig. 11 - area "1") features a peak originating from the $\mathrm{Cr}_{\mathrm{Ka}}$ line; this indicates that chromium is present in this part of the coating material. This is associated with $\mathrm{Cr}$ evaporation during the long-term oxidation of this type of layered system. The deposition of the $\mathrm{Mn}_{1.45} \mathrm{Co}_{1.45} \mathrm{Cu}_{0.1} \mathrm{O}_{4}$ coating on the investigated ferritic steel may therefore not only reduce the rate at which it is oxidized, but also inhibit the evaporation of chromium compounds into the anode side of the SOEC.

From this perspective, the formation of manganese-chromium spinel at the steel/coating interface instead of chromia is also beneficial because of the ability of this spinel to inhibit the diffusion of chromium towards the outer part of the coating [59]. EDS point analysis also revealed the presence of numerous $\mathrm{NbFe}_{2}$ phase precipitates just underneath the intermediate reaction layer located at the steel/coating interface (Fig. 11 - area "3") as well as at grain boundaries in the metallic core.

The concentration of tungsten, chromium and silicon in these precipitates is higher than in the ferritic steel itself (Fig. 11 - area "4"). The composition of the Laves phase may thus be expressed as $(\mathrm{Fe}, \mathrm{Cr})_{2}(\mathrm{Nb}, \mathrm{W})$. Its presence leads to a reduced rate of chromium diffusion towards the coating/ gas interface, which translates to lower oxidation rate of the Crofer $22 \mathrm{H}$ steel. 

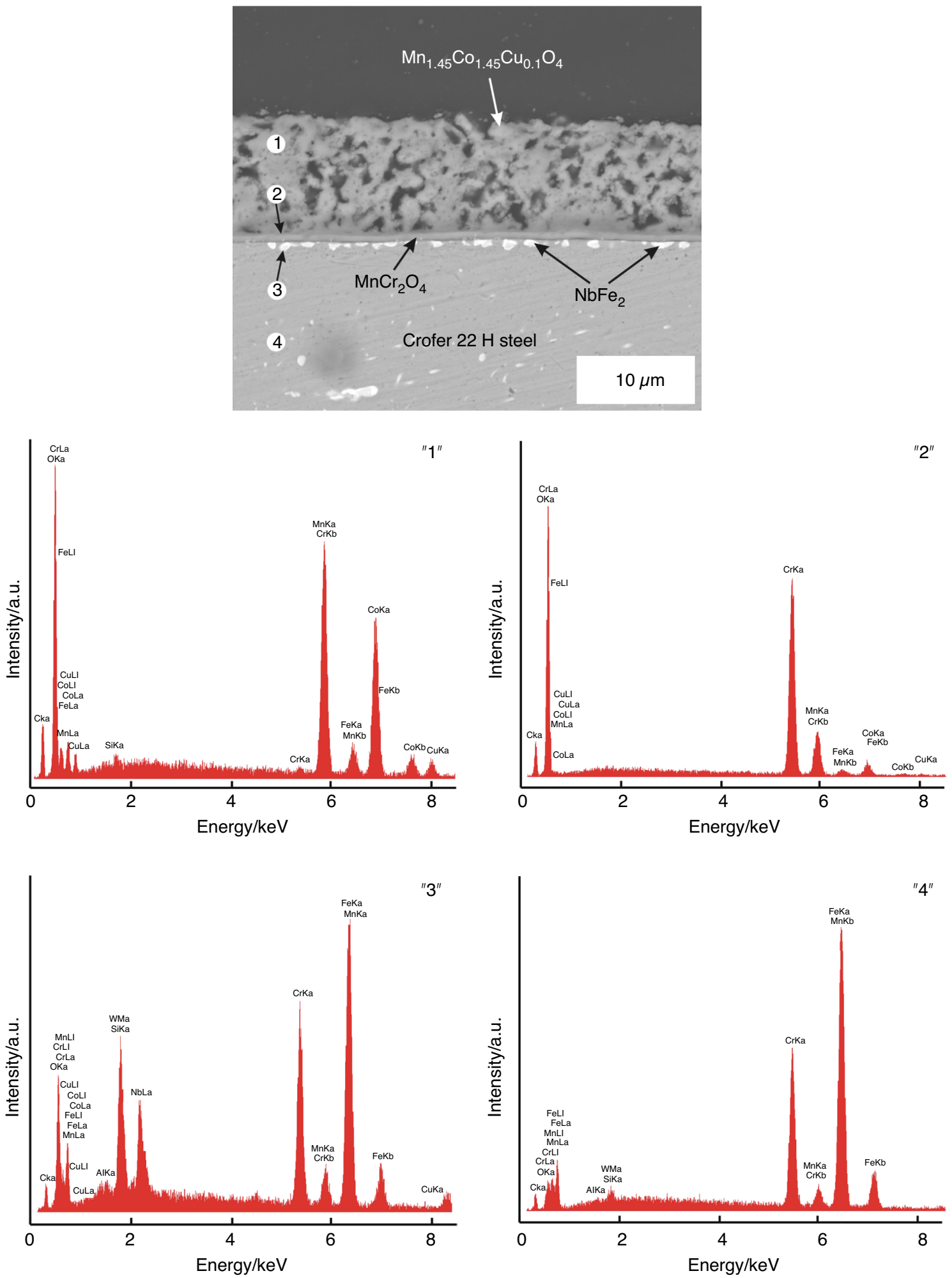

Fig. 11 SEM micrograph of the Crofer $22 \mathrm{H} / \mathrm{Mn}_{1.45} \mathrm{Co}_{1.45} \mathrm{Cu}_{0.1} \mathrm{O}_{4}$ layered system after $1200 \mathrm{~h}$ of cyclic oxidation in air at $800{ }^{\circ} \mathrm{C}$, with EDS point analysis spectra recorded for regions marked "1", "2", "3" and "4" in the micrograph 


\section{Chromium vapouratization rate}

The ability of the $\mathrm{Mn}_{1.45} \mathrm{Co}_{1.45} \mathrm{Cu}_{0.1} \mathrm{O}_{4}$ coating to limit the emission of volatile compounds of chromium from the Crofer $22 \mathrm{H}$ steel substrate was determined by measuring the evaporation rate of $\mathrm{Cr}$. The respective measurements were conducted using the surface of the samples of unmodified Crofer $22 \mathrm{H}$ steel and the two layered systems (Crofer 22 $\mathrm{H} / \mathrm{Mn}_{1.45} \mathrm{Co}_{1.45} \mathrm{Cu}_{0.1} \mathrm{O}_{4}$ and Crofer $22 \mathrm{H} / \mathrm{Mn}_{1.5} \mathrm{Co}_{1.5} \mathrm{O}_{4}$ ), all after the previously described thermal treatment. The Crofer $22 \mathrm{H} / \mathrm{Mn}_{1.5} \mathrm{Co}_{1.5} \mathrm{O}_{4}$ sample was prepared specifically for these measurements, since no relevant data had been reported in the literature and it would have otherwise been impossible to determine the influence of the copper addition to the coating on $\mathrm{Cr}$ volatilization. The tests were conducted at temperatures of 750 and $800{ }^{\circ} \mathrm{C}$, for $72 \mathrm{~h}$, and in a flowing gas atmosphere consisting of humidified air $\left(\mathrm{p}\left(\mathrm{H}_{2} \mathrm{O}\right)=9.72 \times 10^{-2} \mathrm{~atm}\right)$.

Figure 12 shows the results of the above-described measurements, obtained under the assumption that the $\mathrm{CrO}_{2}(\mathrm{OH})_{2}$ molecule is a predominant component of the volatile $\mathrm{Cr}$ compounds formed during the evaporation of $\mathrm{Cr}$ at 750 and $800{ }^{\circ} \mathrm{C}$ [76-78]. Of all studied samples, the Crofer $22 \mathrm{H} /$ scale system exhibited the highest rate of $\mathrm{Cr}$ evaporation. In the case of this sample, which consisted of unmodified steel, the scale formed on its surface was dual-layer, and consisted of an inner layer of chromium(III) oxide and an outer layer in the form of the $\mathrm{MnCr}_{2} \mathrm{O}_{4}$ spinel. Research by Konycheva et al. [92] had shown that the continuous layer of the $\mathrm{MnCr}_{2} \mathrm{O}_{4}$ spinel that forms on the outer part of the $\mathrm{Cr}_{2} \mathrm{O}_{3}$ scale during the oxidation of the Crofer $22 \mathrm{APU}$ at $800{ }^{\circ} \mathrm{C}$ reduces the evaporation rate of $\mathrm{Cr}$ by more than three times compared to the rate observed for an ODS alloy, in the case

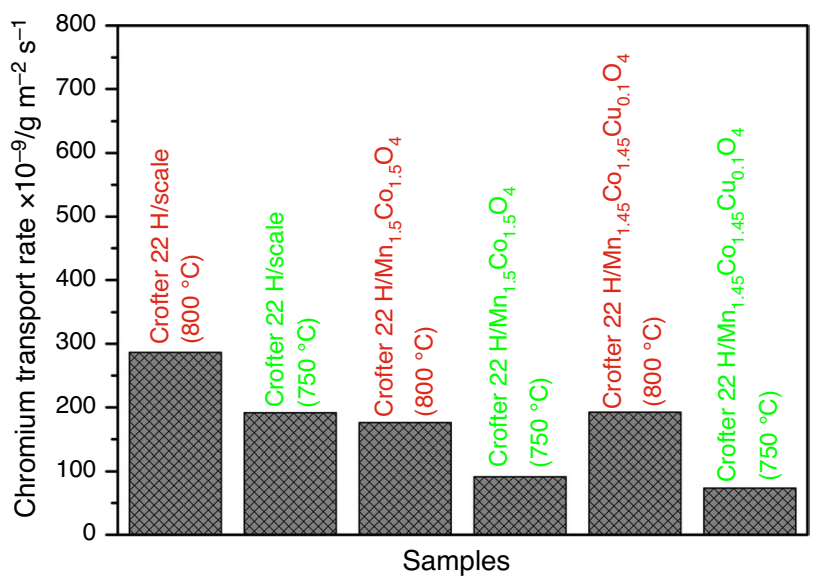

Fig. 12 Chromium transport rate determined for Crofer $22 \mathrm{H}$ steel without any coating and steel coated with either $\mathrm{Mn}_{1.5} \mathrm{Co}_{1.5} \mathrm{O}_{4}$ or $\mathrm{Mn}_{1.45} \mathrm{Co}_{1.45} \mathrm{Cu}_{0.1} \mathrm{O}_{4}$. Test temperature: 750 or $800{ }^{\circ} \mathrm{C}$. Test atmosphere: humidified air of which a single-phase scale composed entirely of chromia is formed.

Although the activity of chromium in the $\mathrm{MnCr}_{2} \mathrm{O}_{4}$ spinel is lower than in chromia, the chromium in the $\mathrm{MnCr}_{2} \mathrm{O}_{4}$ evaporates; this is represented by the mass loss observed in the case of the Crofer $22 \mathrm{H} /$ scale system (Fig. 12). On the other hand, the surface modification of the Crofer $22 \mathrm{H}$ steel with the $\mathrm{Mn}_{1.45} \mathrm{Co}_{1.45} \mathrm{Cu}_{0.1} \mathrm{O}_{4}$ and $\mathrm{Mn}_{1.5} \mathrm{Co}_{1.5} \mathrm{O}_{4}$ ceramic coatings leads to drop in the rate of $\mathrm{Cr}$ evaporation from the surface of the investigated steel/coating layered systems. For the oxidation temperature of $750{ }^{\circ} \mathrm{C}$ and the same test temperature, the Crofer $22 \mathrm{H} / \mathrm{Mn}_{1.45} \mathrm{Co}_{1.45} \mathrm{Cu}_{0.1} \mathrm{O}_{4}$ system is characterized by a mass loss that is ca. $20 \%$ lower than that observed for the second layered system. For the oxidation and test temperature of $800{ }^{\circ} \mathrm{C}$, the opposite tendency was observed (Fig. 12). This is presumably connected with the occurrence of cracks and fissures in the $\mathrm{Mn}_{1.45} \mathrm{Co}_{1.45} \mathrm{Cu}_{0.1} \mathrm{O}_{4}$ coating (Fig. 10b). Another possible explanation is that the copper present in the $\mathrm{Mn}-\mathrm{Co}-\mathrm{O}$ coating may favour the diffusion of a greater amount of chromium in the $\mathrm{Mn}_{1.45} \mathrm{Co}_{1.45} \mathrm{Cu}_{0.1} \mathrm{O}_{4}$ coating than in the $\mathrm{Mn}_{1.5} \mathrm{Co}_{1.5} \mathrm{O}_{4}$ one. This possibility is supported by the results of the study of the $\mathrm{Cr}_{2} \mathrm{O}_{3}-\mathrm{MnCo}_{2} \mathrm{O}_{4}$ diffusion couple oxidized at $900{ }^{\circ} \mathrm{C}$ in dry air, presented in paper [93]; these results indicate that the presence of $\mathrm{Cu}$ in the $\mathrm{Mn}-\mathrm{Co}$ spinel enhances the diffusion of $\mathrm{Cr}$ from $\mathrm{Cr}_{2} \mathrm{O}_{3}$ to $\mathrm{MnCo}_{2} \mathrm{O}_{4}$. In the context of previous achievements concerning the protection of ferritic steels from the effects of chromium evaporation, as reported in $[27,28,94]$, these results may not seem overly impressive. However, given the method used to deposit the ceramic coatings, i.e. electrophoresis, which usually yields porous coating materials, as well as the disadvantageous thermal treatment conditions involving cyclic temperature changes, these results may actually provide a rationale for the design of dense and compact protective coatings effective at preventing the formation of volatile compounds of $\mathrm{Cr}$.

\section{Area-specific resistance}

To determine the electrical properties of the steel/coating layered system and thereby the usefulness of the proposed method used to obtain such systems for application in metallic interconnects for SOECs, electrical resistance measurements were conducted with the use of the 2-probe 4-point method ("Instrumentation" section).

This test was performed for two samples of the Crofer 22 $\mathrm{H} / \mathrm{Mn}_{1.45} \mathrm{Co}_{1.45} \mathrm{Cu}_{0.1} \mathrm{O}_{4}$ layered system, obtained after $1200 \mathrm{~h}$ of cyclic oxidation in air at either 750 or $800{ }^{\circ} \mathrm{C}$. The electrical resistance values measured for the samples over the temperature range from 35 to either 750 or $800{ }^{\circ} \mathrm{C}$-depending on the temperature of the preceding cyclic oxidationwere used to calculate their area-specific resistance (ASR) according to Eq. (4). The determined values as well as the 
corresponding results for the reference samples, i.e. Crofer $22 \mathrm{H} / \mathrm{Mn}_{1.5} \mathrm{Co}_{1.5} \mathrm{O}_{4}$ [74] and Crofer $22 \mathrm{H} /$ scale [74], are presented in Fig. 13, in the form of Arrhenius plots representing the temperature dependence of ASR. Figure 13a shows the ASR data obtained after cyclic oxidation at $750{ }^{\circ} \mathrm{C}$, while Fig. 13b shows those obtained at $800{ }^{\circ} \mathrm{C}$. A linear correlation between the ASR of the samples and temperature can be seen in these plots. The investigated layered systems therefore exhibited a thermally activated character of electrical conduction. Assuming that small polaron hopping is the mechanism responsible for conduction in the studied layered systems, their ASR may be expressed as follows [11]:

$\operatorname{ASR}=\left(\frac{A}{T}\right) \exp \left(\frac{E_{\mathrm{c}}}{k T}\right)$

where: $A$-pre-exponential factor $/ \Omega \mathrm{cm}^{-2} \mathrm{~K}^{-1}, E_{\mathrm{c}}$-activation energy $/ \mathrm{kJ} \mathrm{mol}^{-1}$, $\mathrm{k}-$ Boltzmann constant $/ \mathrm{eV} \mathrm{K}^{-1}$ and $T$-absolute temperature/K.

The linear character of the $\ln (\mathrm{ASR})=f(1 / T)$ dependence allowed the calculation of the activation energy of electrical conduction of the studied Crofer $22 \mathrm{H} / \mathrm{Mn}_{1.45} \mathrm{Co}_{1.45} \mathrm{Cu}_{0.1} \mathrm{O}_{4}$ layered system based on Eq. (8). Table 4 lists the ASR values of the investigated samples, measured at 750 or $800{ }^{\circ} \mathrm{C}$, as well as the activation energy values determined for the two corresponding cyclic oxidation temperatures. Data for the Crofer $22 \mathrm{H} / \mathrm{Mn}_{1.5} \mathrm{Co}_{1.5} \mathrm{O}_{4}$ [74] and Crofer $22 \mathrm{H} /$ scale [74] reference samples are shown for comparison. Whether at 750 or $800{ }^{\circ} \mathrm{C}$, the steel/scale system exhibits the lowest activation energy of conduction $\left(E_{\mathrm{c}}\right)$. Oxidation at $750{ }^{\circ} \mathrm{C}$ results in the highest $\mathrm{E}_{\mathrm{a}}$ value for the Crofer $22 \mathrm{H} / \mathrm{Mn}_{1.5} \mathrm{Co}_{1.5} \mathrm{O}_{4}$ system [74], whereas Crofer $22 \mathrm{H} / \mathrm{Mn}_{1.45} \mathrm{Co}_{1.45} \mathrm{Cu}_{0.1} \mathrm{O}_{4}$ exhibits the highest value when oxidized at $800{ }^{\circ} \mathrm{C}$.

In the case of the samples which had undergone cyclic oxidation at $750{ }^{\circ} \mathrm{C}$, it was found that below a measurement temperature of $550{ }^{\circ} \mathrm{C}$, the ASR value of the investigated Crofer $22 \mathrm{H} / \mathrm{Mn}_{1.45} \mathrm{Co}_{1.45} \mathrm{Cu}_{0.1} \mathrm{O}_{4}$ layered system is comparable (taking into account the measurement error) to that of the Crofer $22 \mathrm{H} / \mathrm{Mn}_{1.5} \mathrm{Co}_{1.5} \mathrm{O}_{4}$ system [74], but significantly lower than the ASR value measured for the Crofer $22 \mathrm{H}$ steel without any surface modification [74]. Moreover, for temperatures below $600{ }^{\circ} \mathrm{C}$ the ASR of this layered system does not exceed the $0.1 \Omega \mathrm{cm}^{2}$ threshold defined for interconnect materials applied in both SOFCs and SOECs [14] (Fig. 13a, Table 4). The fact that its ASR value is at such a low level is related to the absence of a continuous layer of chromia in the intermediate reaction zone in this layered system; chromia exhibits high electrical resistance [73] and is the main oxidation product formed in the case of unmodified ferritic steel [74].

The data presented in Fig. 13b and Table 4 lead to the observation that below $480{ }^{\circ} \mathrm{C}$ the Crofer $22 \mathrm{H} /$ scale layered system exhibits the lowest ASR [74], whereas the Crofer 22
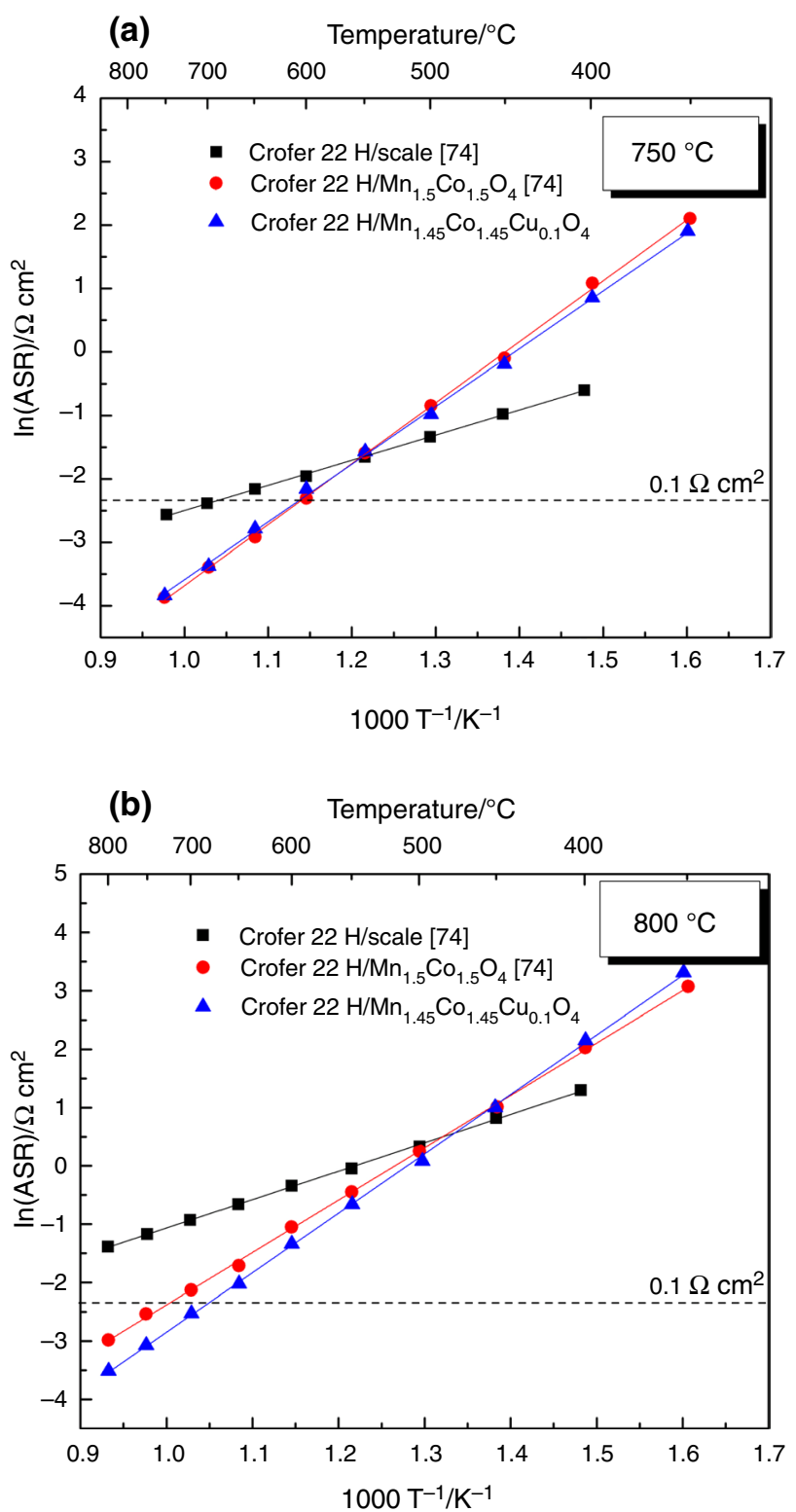

Fig. 13 ASR vs. temperature for the Crofer $22 \mathrm{H} / \mathrm{Mn}_{1.45} \mathrm{Co}_{1.45} \mathrm{Cu}_{0.1} \mathrm{O}_{4}$ system compared to the corresponding dependences of the reference samples (Crofer $22 \mathrm{H} / \mathrm{Mn}_{1.5} \mathrm{Co}_{1.5} \mathrm{O}_{4}$ [74] and Crofer $22 \mathrm{H} /$ scale [74]) after $1200 \mathrm{~h}$ of cyclic oxidation in air at: $\mathbf{a} 750{ }^{\circ} \mathrm{C}$ and $\mathbf{b} 800{ }^{\circ} \mathrm{C}$

$\mathrm{H} / \mathrm{Mn}_{1.5} \mathrm{Co}_{1.5} \mathrm{O}_{4}[74]$ and Crofer $22 \mathrm{H} / \mathrm{Mn}_{1.45} \mathrm{Co}_{1.45} \mathrm{Cu}_{0.1} \mathrm{O}_{4}$ layered systems are characterized by comparable ASR values that are higher than those for the system with unmodified steel. Above $480{ }^{\circ} \mathrm{C}$, the opposite relationship is observed. In the case of the Crofer $22 \mathrm{H}$ steel which had not undergone any surface modification and was oxidized at $800^{\circ} \mathrm{C}$, the ASR measured at this temperature is $0.2449 \Omega \mathrm{cm}^{2}$. This value exceeds the level acceptable for interconnect materials intended for use in electrochemical devices by a large margin. On the other hand, the layered systems consisting of the Crofer $22 \mathrm{H}$ steel and protective-conducting coatings 
Table 4 ASR values measured at 750 and $800{ }^{\circ} \mathrm{C}$ as well as activation energy of electrical conduction for layered systems-steel/scale and two variants of steel/coating-obtained after $1200 \mathrm{~h}$ of cyclic oxidation in air at 750 and $800{ }^{\circ} \mathrm{C}$

\begin{tabular}{llll}
\hline Sample & $\begin{array}{l}\text { Cyclic oxidation } \\
\text { temperature } /{ }^{\circ} \mathrm{C}\end{array}$ & $\mathrm{ASR} / \Omega \mathrm{cm}^{2}$ & $E_{\mathrm{c}} / \mathrm{eV}$ \\
\hline Crofer 22 H/scale [74] & 750 & 0.0772 & 0.342 \\
& 800 & 0.2449 & 0.419 \\
Crofer 22 H/Mn $\mathrm{Mn}_{1.5} \mathrm{Co}_{1.5} \mathrm{O}_{4}$ & 750 & 0.0214 & 0.828 \\
[74] & 800 & 0.0527 & 0.773 \\
Crofer 22 H/ & 750 & 0.0223 & 0.812 \\
$\mathrm{Mn}_{1.45} \mathrm{Co}_{1.45} \mathrm{Cu}_{0.1} \mathrm{O}_{4}$ & 800 & 0.0293 & 0.877 \\
\hline
\end{tabular}

meet this criterion (Table 4). Furthermore, it was determined that introducing copper into the structure of manganesecobalt spinel has an advantageous effect as far as ASR is concerned, leading to a lower value than that observed for the spinel without any copper addition (Fig. 13b, Table 4).

The conducted research leads to the conclusion that the electrophoretic deposition of a protective-conducting coating with the composition of $\mathrm{Mn}_{1.45} \mathrm{Co}_{1.45} \mathrm{Cu}_{0.1} \mathrm{O}_{4}$ on the surface of the Crofer $22 \mathrm{H}$ ferritic steel, combined with the appropriate thermal treatment, should yield a layered system that exhibits improved oxidation resistance and better electrical properties under cyclic oxidation conditions, as compared to the steel/scale system based on unmodified steel. The proposed surface modification of ferritic steel provides the opportunity to construct a metallic interconnect that should enable a failure-free, long-term operation of intermediatetemperature SOECs in which it is implemented.

\section{Conclusions}

- EDTA gel processes were applied to synthesize fine $\mathrm{Mn}_{1.45} \mathrm{Co}_{1.45} \mathrm{Cu}_{0.1} \mathrm{O}_{4}$ powders with a spinel structure. The use of electrophoretic deposition combined with the appropriate thermal treatment made it possible to obtain protective-conducting coatings with strong adhesion to the Crofer $22 \mathrm{H}$ steel substrate.

- Dense single-phase $\mathrm{Mn}_{1.45} \mathrm{Co}_{1.45} \mathrm{Cu}_{0.1} \mathrm{O}_{4}$ sinters were obtained from green bodies via $2 \mathrm{~h}$ of free sintering in air at $1150{ }^{\circ} \mathrm{C}$. These sinters consisted of cubic phase grains. Their electrical conductivity measured at $800{ }^{\circ} \mathrm{C}$ was $48 \mathrm{~S} \mathrm{~cm}^{-1}$.

- The oxidation kinetics study conducted for the Crofer $22 \mathrm{H} / \mathrm{Mn}_{1.45} \mathrm{Co}_{1.45} \mathrm{Cu}_{0.1} \mathrm{O}_{4}$ layered system over 48 -h cycles, in air at temperatures of 750 and $800{ }^{\circ} \mathrm{C}$ and for a total time of $1200 \mathrm{~h}$, showed that the oxidation process approximately follows the parabolic rate law.
The investigated layered system was characterized by better oxidation resistance than steel without any surface modification.

- Investigations of the microstructure of the Crofer 22 $\mathrm{H} / \mathrm{Mn}_{1.45} \mathrm{Co}_{1.45} \mathrm{Cu}_{0.1} \mathrm{O}_{4}$ samples obtained as a result of long-term oxidation at one of the two applied temperatures $\left(750 / 800{ }^{\circ} \mathrm{C}\right)$ confirmed that the coatings deposited electrophoretically on the selected steel substrate and thermally treated in the appropriate manner exhibited strong adhesion to the metallic substrate. SEMEDS observations showed that an intermediate reaction layer consisting of the $\mathrm{MnCr}_{2} \mathrm{O}_{4}$ spinel had formed at the steel/coating interface.

- Measurements of the formation rate of volatile chromium compounds for the Crofer $22 \mathrm{H}$ steel without any modification and after the deposition of one of two coatings- $\mathrm{Mn}_{1.5} \mathrm{Co}_{1.5} \mathrm{O}_{4}$ or $\mathrm{Mn}_{1.45} \mathrm{Co}_{1.45} \mathrm{Cu}_{0.1} \mathrm{O}_{4}$-in a flowing air $/ \mathrm{H}_{2} \mathrm{O}$ mixture and at temperatures of either 750 or $800^{\circ} \mathrm{C}$ demonstrated that these coatings may serve as barriers that effectively prevent the formation of volatile compounds of chromium.

- Measurements of the area-specific resistance of the layered systems obtained after long-term exposure to cyclic temperature changes revealed that the Crofer 22 $\mathrm{H}$ steel modified with the $\mathrm{Mn}_{1.45} \mathrm{Co}_{1.45} \mathrm{Cu}_{0.1} \mathrm{O}_{4}$ coating was characterized by low values of this parameter above 600 and $480{ }^{\circ} \mathrm{C}$ for cyclic oxidation temperatures of 750 and $800{ }^{\circ} \mathrm{C}$, respectively. For both of these temperature ranges, the measured ASR values were below the threshold set for interconnect materials intended for application in solid oxide electrolyzer cells (SOECs).

- The conducted experiments proved that the Crofer 22 $\mathrm{H} / \mathrm{Mn}_{1.45} \mathrm{Co}_{1.45} \mathrm{Cu}_{0.1} \mathrm{O}_{4}$ layered system is a viable interconnect material for application in SOECs.

Acknowledgements This work was supported from the subsidy of the Ministry of Education and Science for the AGH University of Science and Technology in Kraków (Project No 16.16.160.557). We would like to acknowledge the contribution of our late colleague Wiesław Knap from the Department of Hydrogeology and Geological Engineering at the AGH UST Faculty of Geology, Geophysics and Environmental Protection, who performed the required ICP-OES analysis.

Open Access This article is licensed under a Creative Commons Attribution 4.0 International License, which permits use, sharing, adaptation, distribution and reproduction in any medium or format, as long as you give appropriate credit to the original author(s) and the source, provide a link to the Creative Commons licence, and indicate if changes were made. The images or other third party material in this article are included in the article's Creative Commons licence, unless indicated otherwise in a credit line to the material. If material is not included in the article's Creative Commons licence and your intended use is not permitted by statutory regulation or exceeds the permitted use, you will need to obtain permission directly from the copyright holder. To view a copy of this licence, visit http://creativecommons.org/licenses/by/4.0/. 


\section{References}

1. Ni M, Leung MKH, Leung DYC. Technological development of hydrogen production by solid oxide electrolyzer cell (SOEC). Int J Hydrog Energy. 2008;33:2337-54.

2. Brisse A, Schefold J, Zahid M. High temperature water electrolysis in solid oxide cells. Int J Hydrog Energy. 2008;33:5375-82.

3. Laguna-Bercero MA. Recent advances in high temperature electrolysis using solid oxide fuel cells: a review. J Power Sources. 2012;203:4-16.

4. Shi Y, Cai N, Cao T, Zhang J. High-temperature electrochemical energy conversion and storage. Fundamentals and applications. CRC Press; 2018.

5. Zhou DQ, Meng FY, Bai Y, Cai S. Energy efficiency and congestion assessment with energy mix effect: the case of APEC countries. J Clean Prod. 2016;142:819-28.

6. Schakel W, Oreggioni G, Singh B, Strømman A, Ramírez A. Assessing the techno-environmental performance of $\mathrm{CO}_{2}$ utilization via dry reforming of methane for the production of dimethyl ether. J CO2 Util. 2016;16:138-49.

7. Cullear-Franca RM, Azapagic A. Review Article: Carbon capture, storage and utilisation technologies, A critical analysis and comparison of their life cycle environmental impact. J CO2 Util. 2015;9:82-102.

8. Herring JS, O'Brien JE, Stoots CM, Hawkes GL, Hartvigsen JJ, Shahnam M. Progress in high-temperature electrolysis for hydrogen production using planar SOFC technology. Int J Hydrog Energy. 2007;32:440-50.

9. Fergus JW. Metallic interconnects for solid oxide fuel cells. Mater Sci Eng A. 2005;397:271-83.

10. Quadakkers WJ, Piron-Abellan J, Shemet V, Singheiser L. Metallic interconnectors for solid oxide fuel cells-a review. Mater High Temp. 2003;20:115-27.

11. Yang Z, Weil KS, Paxton DM, Stevenson JW. Selection and evaluation of heat-resistant alloys for SOFC interconnect applications. J Electrochem Soc. 2003;150:A1188-201.

12. Brylewski T, Nanko M, Maruyama T, Przybylski K. Application of $\mathrm{Fe}-16 \mathrm{Cr}$ ferritic alloy to interconnector for a solid oxide fuel cell. Solid State Ion. 2001;143:131-40.

13. Molin S, Chen M, Bentzen JJ, Hendriksen PV. High temperature oxidation of ferritic steels for solid oxide electrolysis stacks. ECS Trans. 2013;50:11-20.

14. Zhu WZ, Deevi SC. Development of interconnect materials for solid oxide fuel cells. Mater Sci Eng A. 2003;348:227-43.

15. Fontana S, Amendola R, Chevalier S, Piccardo P, Caboche G, Viviani M, Molins R, Sennour M. Metallic interconnects for SOFC: characterisation of corrosion resistance and conductivity evaluation at operating temperature of differently coated alloys. J Power Sources. 2007;171:652-62.

16. Cabouro G, Caboche G, Chevalier S, Piccardo P. Opportunity of metallic interconnects for ITSOFC: Reactivity and electrical property. J Power Sources. 2006;156:39-44.

17. High-temperature Solid Oxide Fuel Cells for the 21st Century. Fundamentals, Design and Applications; eds Kendall K. and Kendall M.; Elsevier Ltd.; London; 2016.

18. Grolig JG, Froitzheim J, Svensson J-E. Coated stainless steel 441 as interconnect material for solid oxide fuel cells: oxidation performance and chromium evaporation. J Power Sources. 2014;248:1007-13.

19. Bian L, Chen Z, Wang L, Li F, Chou K. Oxidation resistance, thermal expansion and area specific resistance of $\mathrm{Fe}-\mathrm{Cr}$ alloy interconnector for solid oxide fuel cell. J Iron Steel Res Int. 2017;24:77-83.

20. Bianco M, Linder M, Larring Y, Greco F, Herle JV. Chapter 7Lifetime Issues for Solid Oxide Fuel Cell Interconnects, Solid
Oxide Fuel Cell Lifetime and Reliability, Critical Challenges in Fuel Cells; 2017. pp. 121-44.

21. Hilpert K, Das D, Miller M, Peck DH, Wei R. Chromium vapor species over solid oxide fuel cell interconnect materials and their potential for degradation processes. J Electrochem Soc. 1996;143:3642-7.

22. Sachitanand R, Sattari M, Svensson J-E, Froitzheim J. Evaluation of the oxidation and $\mathrm{Cr}$ evaporation properties of selected $\mathrm{FeCr}$ alloys used as SOFC interconnects. Int J Hydrog Energy. 2013;38:15328-34.

23. Smeacetto F, Salvo M, Leone P, Santarelli M, Ferraris M. Performance and testing of joined Crofer 22 APU-glass-ceramic sealant-anode supported cell in SOFC relevant conditions. Mater Lett. 2011;65:1048-52.

24. Lee S, Chu C-L, Tsai M-J, Lee J. High temperature oxidation behavior of interconnect coated with LSCF and LSM for solid oxide fuel cell by screen printing. Appl Surf Sci. 2010;256:1817-24.

25. Yang $\mathrm{X}, \mathrm{Tu} \mathrm{H}, \mathrm{Yu}$ Q. Fabrication of $\mathrm{Co}_{3} \mathrm{O}_{4}$ and $\mathrm{La}_{0.6} \mathrm{Sr}_{0.4} \mathrm{CoO}_{3-\delta}-\mathrm{Ce}_{0.8} \mathrm{Gd}_{0.2} \mathrm{O}_{2-\delta}$ dual layer coatings on SUS430 steel by in-situ phase formation for solid oxide fuel cell interconnects. Int J Hydrog Energy. 2015;40:607-14.

26. Przybylski K, Brylewski T, Durda E, Gaweł RA, Kruk A. Oxidation properties of the Crofer 22 APU steel coated with $\mathrm{La}_{0.6} \mathrm{Sr}_{0.4} \mathrm{Co}_{0.2} \mathrm{Fe}_{0.8} \mathrm{O}_{3}$ for IT-SOFC interconnect applications. J Therm Anal Calorim. 2014;116:825-34.

27. Kruk A, Stygar M, Brylewski T. Mn-Co spinel protectiveconductive coatings on AL453 ferritic stainless steel for ITSOFC interconnect application. J Solid State Electrochem. 2013; 17:993-1003.

28. Brylewski T, Kruk A, Bobruk M, Adamczyk A, Partyka J, Rutkowski P. Structure and electrical properties of $\mathrm{Cu}$-doped $\mathrm{Mn}-$ Co-O spinel prepared via soft chemistry and its application in IT-SOFC interconnects. J Power Sources. 2016;333:145-55.

29. Gil A, Wyrwa J, Brylewski T. Improving the oxidation resistance and electrical properties of ferritic stainless steels for application in SOFC interconnects. Oxid Met. 2016;85:151-69.

30. Molin S. Evaluation of electrodeposited $\mathrm{Mn}-\mathrm{Co}$ protective coatings on Crofer 22 APU steel. Int J Appl Ceram Tec. 2017;15:349-60.

31. Mosavi A, Ebrahimifar H. Investigation of oxidation and electrical behavior of AISI 430 steel coated with $\mathrm{Mn}-\mathrm{Co}-\mathrm{CeO}_{2}$ composite. Int J Hydrog Energy. 2020;45:3145-62.

32. Gan L, Murakami H, Saeki I. Effect of W content on the oxidation and electrical behaviors of $\mathrm{Co}-\mathrm{W}$ coatings for SOFC interconnects fabricated by electrodeposition. Mater Trans. 2020;61:490-6.

33. Saeidpour F, Zandrahimi M, Ebrahimifar H. Evaluation of pulse electroplated cobalt/yttrium oxide composite coating on the Crofer 22 APU stainless steel interconnect. Int J Hydrog Energy. 2019;443:3157-69.

34. Saeidpour F, Zandrahimi M, Ebrahimifar H. Effect of $\mathrm{ZrO}_{2}$ particles on oxidation and electrical behavior of Co coatings electroplated on ferritic stainless steel interconnect. Corros Sci. 2019;153:200-12.

35. Yang Z, Xia G-G, Maupin GD, Stevenson JW. Conductive protection layers on oxidation resistant alloys for SOFC interconnect applications. Surf Coat Technol. 2006;201:4476-83.

36. $\mathrm{Hu}$ Y-Z, Su Y-T, Li C-X, Li C-J, Yang G-J. Dense $\mathrm{Mn}_{1.5} \mathrm{Co}_{1.5} \mathrm{O}_{4}$ coatings with excellent long-term stability and electrical performance under the SOFC cathode environment. Appl Surf Sci. 2020. https://doi.org/10.1016/j.apsusc.2019.143726.

37. Garcia-Vargas MJ, Zahid M, Tietz F, Aslnides A. Use of SOFC metallic interconnect coated with spinel protective layers using the APS technology. ECS Trans. 2007;7:2399-405. 
38. Gannon P, Deibert M, White P, Smith R, Chen H, Priyantha W, Lucas J, Gorokhovsky V. Advanced PVD protective coatings for SOFC interconnects. Int J Hydrog Energy. 2008;33:3991-4000.

39. Yang Z, Xia GG, Li XH, Stevenson JW. $(\mathrm{Mn}, \mathrm{Co})_{3} \mathrm{O}_{4}$ spinel coatings on ferritic stainless steels for SOFC interconnect applications. Int J Hydrog Energy. 2007;32:3648-54.

40. Mardare CC, Spiegel M, Savan A, Ludwig A. Thermally oxidized $\mathrm{Mn}-\mathrm{Co}$ thin films as protective coatings for SOFC interconnects. J Electrochem Soc. 2009;156:B1431-9.

41. Yang Z, Xia G, Simner SP, Stevenson JW. Thermal growth and performance of manganese cobaltite spinel protection layers on ferritic stainless steel SOFC interconnects. J Electrochem Soc. 2005;152:A1896-901.

42. Brylewski T, Kruk A, Adamczyk A, Kucza W, Przybylski K. Synthesis and characterization of the manganese cobaltite spinel prepared using two "soft chemical" methods. Mater Chem Phys. 2012;137:310-6.

43. Brylewski T, Kucza W, Adamczyk A, Kruk A, Stygar M, Bobruk $\mathrm{M}$, Dąbrowa J. Microstructure and electrical properties of $\mathrm{Mn}_{1+\mathrm{x}} \mathrm{Co}_{2-\mathrm{x}} \mathrm{O}_{4}(0 \leq \mathrm{x} \leq 1.5)$ spinels synthesized using EDTAgel processes. Ceram Int. 2014;40:13873-82.

44. Molin S, Sabato AG, Bindi M, Leone P, Cempura G, Salvo M, Polo SC, Boccaccini AR, Smeacetto F. Microstructural and electrical characterization of $\mathrm{Mn}-\mathrm{Co}$ spinel protective coatings for solid oxide cell interconnects. J Eur Ceram Soc. 2017;37:4781-91.

45. Bobruk M, Brylewska K, Durczak K, Wojciechowski K, Adamczyk A, Brylewski T. Synthesis of manganese-cobalt spinel via wet chemistry methods and its properties. Ceram Int. 2017;43:15597-609.

46. Szymczewska D, Molin S, Venkatachalam V, Chen M, Jasinski P, Hendriksen PV. Assessment of $(\mathrm{Mn}, \mathrm{Co})_{3} \mathrm{O}_{4}$ powders for possible coating material for SOFC/SOEC interconnects. IOP Conf Ser Mater Sci Eng. 2015;104:1-9.

47. Hosseini N, Karimzadeh F, Abbasi MH, Choi GM. Microstructural characterization and electrical conductivity of $\mathrm{Cu}_{\mathrm{x}} \mathrm{Mn}_{3-\mathrm{x}} \mathrm{O}_{4}$ $(0.9 \leq \mathrm{x} \leq 1.3)$ spinels produced by optimized glycine-nitrate combustion and mechanical milling processes. Ceram Int. 2014;40:12219-26.

48. Hosseini N, Abbasi MH, Karimzadeh F, Choi GM. Development of $\mathrm{Cu}_{1.3} \mathrm{Mn}_{1.7} \mathrm{O}_{4}$ spinel coating on ferritic stainless steel for solid oxide fuel cell interconnects. J Power Sources. 2015;273:1073-83.

49. Bobruk M, Durczak K, Dąbek J, Brylewski T. Structure and electrical properties of $\mathrm{Mn}-\mathrm{Cu}-\mathrm{O}$ spinels. J Mater Eng Perform. 2017;26:1598-604.

50. Xu Y, Wen Z, Wang S, Wen T. Cu doped Mn-Co spinel protective coating on ferritic stainless steels for SOFC interconnect applications. Solid State Ion. 2011;192:561-4.

51. Park B-K, Lee J-W, Lee S-B, Lim T-H, Park SJ, Park C-O, Song $\mathrm{R}-\mathrm{H}$. Cu- and Ni-doped $\mathrm{Mn}_{15} \mathrm{Co}_{1.5} \mathrm{O}_{4}$ spinel coatings on metallic interconnects for solid oxide fuel cells. Int J Hydrog Energy. 2013;38:12043-50.

52. Chen G, Xin X, Luo T, Liu L, Zhou Y, Yuan C, Lin C, Zhan Z, Wang S. $\mathrm{Mn}_{1.4} \mathrm{Co}_{1.4} \mathrm{Cu}_{0.2} \mathrm{O}_{4}$ spinel protective coating on ferritic stainless steels for solid oxide fuel cell interconnect applications. J Power Sources. 2015;278:230-4.

53. Lee K, Yoon B, Kang J, Lee S, Bae J. Evaluation of Ag-doped $(\mathrm{MnCo})_{3} \mathrm{O}_{4}$ spinel as a solid oxide fuel cell metallic interconnect coating material. Int J Hydrog Energy. 2017;42:29511-7.

54. Talic B, Molin S, Wiik K, Hendriksen PV, Lein HL. Comparison of iron and copper doped manganese cobalt spinel oxides as protective coatings for solid oxide fuel cell interconnects. J Power Sources. 2017;372:145-56.

55. Molin S, Jasiński P, Mikkelsen L, Zhang W, Chen M, Hendriksen PV. Low temperature processed $\mathrm{MnCo}_{2} \mathrm{O}_{4}$ and $\mathrm{MnCo}_{18} \mathrm{Fe}_{0.2} \mathrm{O}_{4}$ as effective protective coatings for solid oxide fuel cell interconnects at $750^{\circ} \mathrm{C}$. J Power Sources. 2016;336:408-18.
56. Thaheem I, Joh DW, Noh T, Lee KT. Highly conductive and stable $\mathrm{Mn}_{1.35} \mathrm{Co}_{1.35} \mathrm{Cu}_{0.2} \mathrm{Y}_{0.1} \mathrm{O}_{4}$ spinel protective coating on commercial ferritic stainless steels for intermediate-temperature solid oxide fuel cell interconnect applications. Int J Hydrogen Energy. 2019;44:4293-303.

57. Stevenson JW, Yang ZG, Xia GG, Nie Z, Templeton JD. Longterm oxidation behavior of spinel-coated ferritic stainless steel for solid oxide fuel cell interconnect applications. J Power Sources. 2013;231:256-63.

58. Petric A, Ling H. Electrical conductivity and thermal expansion of spinels at elevated temperatures. J Am Ceram Soc. 2007;90:1515-20.

59. Shaigan N, Qu W, Ivey DG, Chen W. A review of recent progress in coatings, surface modifications and alloy developments for solid oxide fuel cell ferritic stainless steel interconnects. J Power Sources. 2010;195:1529-42.

60. Miguel-Pérez V, Martínez-Amesti A, Nó ML, Larrañaga A, Arriortua MI. The effect of doping $(\mathrm{Mn}, \mathrm{B})_{3} \mathrm{O}_{4}$ materials as protective layers in different metallic interconnects for Solid Oxide Fuel Cells. J Power Sources. 2013;243:419-30.

61. Stanislowski M, Froitzheim J, Niewolak L, Quadakkers WJ, Hilpert K, Markus T, Singheiser L. Reduction of chromium vaporization from SOFC interconnectors by highly effective coatings. J Power Sources. 2007;164:578-89.

62. Talic B, Falk-Windisch H, Venkatachalam V, Hendriksen PV, Wiik K, Lein HL. Effect of coating on oxidation resistance and $\mathrm{Cr}$ vaporization from solid oxide fuel cell interconnects. J Power Sources. 2017;354:57-67.

63. Abdoli $\mathrm{H}$, Alizadeh P. Electrophoretic deposition of $(\mathrm{Mn}, \mathrm{Co})_{3} \mathrm{O}_{4}$ spinel nano powder on SOFC metallic interconnects. Mater Lett. 2012;80:53-5.

64. Zhang H, Zhan Z, Liu X. Electrophoretic deposition of $(\mathrm{Mn}, \mathrm{Co})_{3} \mathrm{O}_{4}$ spinel coating for solid oxide fuel cell interconnects. J Power Sources. 2011;196:8041-7.

65. Bobruk M, Molin S, Chen M, Brylewski T, Hendriksen PV. Sintering of $\mathrm{MnCo}_{2} \mathrm{O}_{4}$ coatings prepared by electrophoretic deposition. Mater Lett. 2018;213:394-8.

66. Smeacetto F, Miranda AD, Polo SC, Molin S, Boccaccini D, Salvo M, Boccaccini AR. Electrophoretic deposition of $\mathrm{Mn}_{1.5} \mathrm{Co}_{1.5} \mathrm{O}_{4}$ on metallic interconnect and interaction with glass-ceramic sealant for solid oxide fuel cells application. J Power Sources. 2015;280:379-86.

67. Zanchi E, Talic B, Sabato AG, Molin S, Boccaccini AR, Smeacetto F. Electrophoretic co-deposition of $\mathrm{Fe}_{2} \mathrm{O}_{3}$ and $\mathrm{Mn}_{1,5} \mathrm{Co}_{1,5} \mathrm{O}_{4}$ : Processing and oxidation performance of $\mathrm{Fe}$ doped Mn-Co coatings for solid oxide cell interconnects. J Eur Ceram Soc. 2019;39:3768-77.

68. Sabato AG, Molin S, Javed H, Zanchi E, Boccaccini AR, Smeacetto F. In-situ Cu-doped MnCo-spinel coatings for solid oxide cell interconnects processed by electrophoretic deposition. Ceram Int. 2019;45:19148-57.

69. Talic B. Metallic Interconnects for Solid Oxide Fuel Cells: High Temperature Corrosion and Protective Spinel Coatings (Ph.D. thesis). Publisher NTNU, Series Doctoral thesis at NTNU; 2016:221; 2016.

70. Xiao J, Zhang W, Xiong C, Chi B, Pu J, Jian L. Oxidation of $\mathrm{MnCu}_{0.5} \mathrm{Co}_{1.5} \mathrm{O}_{4}$ spinel coated SUS430 alloy interconnect in anode and cathode atmospheres for intermediate temperature solid oxide fuel cell. Int J Hydrogen Energy. 2015;40:1868-76.

71. Montero X, Tietz F, Sebold D, Buchkremer HP, Ringuede A, Cassir M, Laresgoiti A, Villarreal I. $\mathrm{MnCo}_{1.9} \mathrm{Fe}_{0.1} \mathrm{O}_{4}$ spinel protection layer on commercial ferritic steels for interconnect applications in solid oxide fuel cells. J Power Sources. 2008;184:172-9.

72. Legros R, Metz R, Rousset A. The preparation, characterization and electrical properties of electroceramics made of copper-cobalt 
manganite spinel: $\mathrm{Mn}_{2.6 \mathrm{x}} \mathrm{Co}_{0.4} \mathrm{Cu}_{\mathrm{x}} \mathrm{O}_{4}, 0 \leq \mathrm{x} \leq 1$. $\mathrm{J}$ Eur Ceram Soc. 1995;15:463-8.

73. Huczkowski P, Quadakkers WJ. Effect of geometry and composition of $\mathrm{Cr}$ steels on oxide scale properties relevant for interconnector applications in solid oxide fuel cells (SOFCs). Schriften des Forschungszentrums Jülich Vol. 65; Forschungszentrum Jülich; 2007.

74. Bednarz M, Molin S, Bobruk M, Stygar M, Długoń E, Sitarz M, Brylewski T. High-temperature oxidation of the Crofer $22 \mathrm{H}$ ferritic steel with $\mathrm{Mn}_{1.45} \mathrm{Co}_{1.45} \mathrm{Fe}_{0.1} \mathrm{O}_{4}$ and $\mathrm{Mn}_{1.5} \mathrm{Co}_{1.5} \mathrm{O}_{4}$ spinel coatings under thermal cycling conditions and its properties. Mater Chem Phys. 2019;225:227-38.

75. Scherrer P. Göttinger Nachrichten Gesell. 1918;2:98.

76. Kurokawa H, Jacobson CP, De Jonghe LC, Visco S. Chromium vaporization of bare and of coated iron-chromium alloys at 1073 K. Solid State Ion. 2007;178:287-96.

77. Brylewski T. Metallic interconnects in a metal/ceramics system for application in solid oxide fuel cells: ed. Wyd. Naukowe "Akapit"; Krakow; 2008 (in polish).

78. Brylewski T, Przybylski K. Oxidation properties of coated Fe$25 \mathrm{Cr}$ steel with regard to the chromium vaporization effects under SOFC cathode operation conditions. Ann Chim Sci Mater. 2008;33:75-82.

79. Chevalier S, Caboche G, Przybylski K, Brylewski T. Effect of nano-layered coatings on the electrical conductivity of oxide scale grown on ferritic steels. J Appl Electrochem. 2009;39:529-34.

80. Naka $\mathrm{S}$, Inagaki M, Tanaka T. On the formation of solid solution in $\mathrm{Co}_{3-x} \mathrm{Mn}_{x} \mathrm{O}_{4}$ system. J Mater Sci. 1972;7:441-4.

81. Aukrust E, Muan A. Phase relations in the system cobalt oxidemanganese oxide in air. J Am Ceram Soc. 1963;46:511.

82. Brabers VAM, Setten FV. X-ray photoelectron spectroscopy study of the ionic configuration of the spinel $\mathrm{CuMnCoO}_{4}$. J Phys Appl Phys. 1983;16:L169-72.

83. Wright PA, Natarajan S, Thomas JM, Gai-Boyes PL. Mixed-metal amorphous and spinel phase oxidation catalysts: characterization by X-ray diffraction, X-ray absorption, electron microscopy, and catalytic studies of systems containing copper, cobalt, and manganese. Chem Mater. 1992;4:1053-65.
84. Yang BL, Chan SF, Chang WS, Chen YZ. Surface enrichment in mixed oxides of $\mathrm{Cu} \mathrm{Co}$, and $\mathrm{Mn}$, and its effect on $\mathrm{CO}$ oxidation. J Catal. 1991;130:52-61.

85. VDM® Crofer 22 H; Material Data Sheet No. 4050; June 2010 Edition.

86. Talic B, Hendriksen PV, Wiik K, Lein HL. Thermal expansion and electrical conductivity of $\mathrm{Fe}$ and $\mathrm{Cu}$ doped $\mathrm{MnCo}_{2} \mathrm{O}_{4}$ spinel. Solid State Ion. 2018;326:90-9.

87. Lu Z, Zhu J, Payzant EA, Paranthaman MP. Electrical conductivity of the manganese chromite spinel solid solution. J Am Ceram Soc. 2005;88:1050-3.

88. Macklen ED. Electric conductivity and cation distribution in nickel manganite. J Phys Chem Solids. 1986;47:1073-9.

89. Verwey EJW. Semiconducting Materials. Butterworths; ed. Scientific Publications; London; 1951.

90. Bordeneuve H, Tenailleau C, Guillemet-Fritsch S, Smith R, Suard E, Rousset A. Structural variations and cation distributions in $\mathrm{Mn}_{3-x} \mathrm{Co}_{x} \mathrm{O}_{4}(0 \leq \mathrm{x} \leq 3)$ dense ceramics using neutron diffraction data. Solid State Sci. 2010;12:379-86.

91. Mrowec S, Werber T. Modern scalling-resistant materials. Ed. national Bureau of Standards and national Science Foundation; Washington DC; 1982.

92. Konycheva E, Penkalla H, Wessel E, Seeling U, Singheiser L, Hilpert K. Solid Oxide Fuel Cells IX (SOFC IX) - Electrochemistry Society Proceedings PV 2005-07. S.C.Singhal, J.Mizusaki, editors. The Electrochemical Society; Pennington; NJ; 2005. p.1874.

93. Talic B, Hendriksen PV, Wiik KI, Lein HL. Diffusion couple study of the interaction between $\mathrm{Cr}_{2} \mathrm{O}_{3}$ and $\mathrm{MnCo}_{2} \mathrm{O}_{4}$ doped with $\mathrm{Fe}$ and $\mathrm{Cu}$. Solid State Ion. 2019;332:16-24.

94. Brylewski T, Dąbek J, Przybylski K, Morgiel J, Rękas M. Screenprinted ( $\mathrm{La}, \mathrm{Sr}) \mathrm{CrO}_{3}$ coatings on ferritic stainless steel interconnects for SOFCs using nanopowders prepared by means of ultrasonic spray pyrolysis. J Power Sources. 2012;208:86-95.

Publisher's Note Springer Nature remains neutral with regard to jurisdictional claims in published maps and institutional affiliations. 